\title{
Fossil vs. non-fossil sources of fine carbonaceous aerosols in four Chinese cities during the extreme winter haze episode of 2013
}

\author{
Y.-L. Zhang ${ }^{1,2,3,4}$, R.-J. Huang ${ }^{2,6}$, I. El Haddad ${ }^{2}$, K.-F. Ho ${ }^{5,6}$, J.-J. Cao ${ }^{6}$, Y. Han ${ }^{6}$, P. Zotter ${ }^{2}$, C. Bozzetti ${ }^{2}$, \\ K. R. Daellenbach ${ }^{2}$, F. Canonaco ${ }^{2}$, J. G. Slowik ${ }^{2}$, G. Salazar ${ }^{1,3}$, M. Schwikowski ${ }^{2,3}$, J. Schnelle-Kreis ${ }^{7}$, G. Abbaszade ${ }^{7}$, \\ R. Zimmermann ${ }^{7,8}$, U. Baltensperger ${ }^{2}$, A. S. H. Prévôt ${ }^{2}$, and S. Szidat ${ }^{1,3}$ \\ ${ }^{1}$ Department of Chemistry and Biochemistry, University of Bern, Freiestrasse 3, 3012 Bern, Switzerland \\ ${ }^{2}$ Paul Scherrer Institute (PSI), Villigen, 5232 Villigen-PSI, Switzerland \\ ${ }^{3}$ Oeschger Centre for Climate Change Research, University of Bern, 3012 Bern, Switzerland \\ ${ }^{4}$ Yale-NUIST Center on Atmospheric Environment, Nanjing University of Information Science \\ and Technology, Nanjing, Jiangsu, China \\ ${ }^{5}$ School of Public Health and Primary Care, Chinese University of Hong Kong, Hong Kong, China \\ ${ }^{6}$ Key Laboratory of Aerosol Chemistry and Physics, Institute of Earth Environment, \\ Chinese Academy of Sciences, 710061 Xi'an, China \\ ${ }^{7}$ Helmholtz Zentrum München, German Research Center for Environmental Health (GmbH), \\ Joint Mass Spectrometry Centre, Cooperation Group Comprehensive Molecular Analytics, \\ and Helmholtz Virtual Institute of Complex Molecular Systems in Environmental Health - \\ Aerosol and Health (HICE), 85764 Neuherberg, Germany \\ ${ }^{8}$ University of Rostock, Joint Mass Spectrometry Centre, Institute of Chemistry - \\ Chair of Analytical Chemistry, 18015 Rostock, Germany
}

Correspondence to: Y. L. Zhang (dryanlinzhang@gmail.com) and S. Szidat (szidat@dcb.unibe.ch)

Received: 8 September 2014 - Published in Atmos. Chem. Phys. Discuss.: 20 October 2014

Revised: 6 January 2015 - Accepted: 8 January 2015 - Published: 6 February 2015

\begin{abstract}
During winter 2013, extremely high concentrations (i.e., 4-20 times higher than the World Health Organization guideline) of $\mathrm{PM}_{2.5}$ (particulate matter with an aerodynamic diameter $<2.5 \mu \mathrm{m}$ ) mass concentrations ( $24 \mathrm{~h}$ samples) were found in four major cities in China including Xi'an, Beijing, Shanghai and Guangzhou. Statistical analysis of a combined data set from elemental carbon (EC), organic carbon (OC), ${ }^{14} \mathrm{C}$ and biomass-burning marker measurements using Latin hypercube sampling allowed a quantitative source apportionment of carbonaceous aerosols. Based on ${ }^{14} \mathrm{C}$ measurements of EC fractions (six samples each city), we found that fossil emissions from coal combustion and vehicle exhaust dominated EC with a mean contribution of $75 \pm 8 \%$ across all sites. The remaining $25 \pm 8 \%$ was exclusively attributed to biomass combustion, consistent with the measurements of biomass-burning markers such as anhydrosugars (levoglucosan and mannosan) and water-soluble potassium $\left(\mathrm{K}^{+}\right)$. With a combination of the levoglucosan-to-
\end{abstract}

mannosan and levoglucosan-to- $\mathrm{K}^{+}$ratios, the major source of biomass burning in winter in China is suggested to be combustion of crop residues. The contribution of fossil sources to OC was highest in Beijing (58 $\pm 5 \%$ ) and decreased from Shanghai $(49 \pm 2 \%)$ to Xi' an $(38 \pm 3 \%)$ and Guangzhou $(35 \pm 7 \%)$. Generally, a larger fraction of fossil OC was from secondary origins than primary sources for all sites. Nonfossil sources accounted on average for $55 \pm 10$ and $48 \pm 9 \%$ of $\mathrm{OC}$ and total carbon (TC), respectively, which suggests that non-fossil emissions were very important contributors of urban carbonaceous aerosols in China. The primary biomassburning emissions accounted for $40 \pm 8,48 \pm 18,53 \pm 4$ and $65 \pm 26 \%$ of non-fossil OC for Xi' an, Beijing, Shanghai and Guangzhou, respectively. Other non-fossil sources excluding primary biomass burning were mainly attributed to formation of secondary organic carbon (SOC) from non-fossil precursors such as biomass-burning emissions. For each site, we also compared samples from moderately to heavily polluted 
days according to particulate matter mass. Despite a significant increase of the absolute mass concentrations of primary emissions from both fossil and non-fossil sources during the heavily polluted events, their relative contribution to TC was even decreased, whereas the portion of SOC was consistently increased at all sites. This observation indicates that SOC was an important fraction in the increment of carbonaceous aerosols during the haze episode in China.

\section{Introduction}

Driven by continuous urbanization and industrialization and a rapid growth in the number of motor vehicles and energy consumption, large-scale severe air pollution episodes often affect most cities in China. An increase in the number of haze days is expected to have an adverse impact on human health (Chan and Yao, 2008). Atmospheric fine particles such as $\mathrm{PM}_{2.5}$ (particulate matter with an aerodynamic diameter of below $2.5 \mu \mathrm{m}$ ) have been reported as an important air pollutant in China (Donkelaar et al., 2010; Yang et al., 2011; Cao et al., 2012; Huang et al., 2013; Zhao et al., 2013), and its burden is much higher than the $24 \mathrm{~h}$ mean of $25 \mu \mathrm{g} \mathrm{m}^{-3}$ suggested by the Air Quality Guidelines of the of World Health Organization (WHO) (WHO, 2006).

Carbonaceous aerosols are a major fraction of $\mathrm{PM}_{2.5}$, contributing $20-50 \%$ of the total PM mass in China's urban atmosphere (Cao et al., 2007). In addition to health and visibility effects, carbonaceous aerosols also influence the earth's climate directly by scattering and absorbing solar radiation and indirectly by modifying cloud microphysics (Pöschl, 2005; IPCC, 2013). Carbonaceous aerosols (total carbon, TC) can be classified into elemental carbon (EC) and organic carbon (OC). EC is exclusively emitted as primary aerosols from incomplete combustion of fossil fuels and biomass burning, whereas $\mathrm{OC}$ is a complex mixture of primary directly emitted $\mathrm{OC}$ particles (POC) and secondary OC (SOC) formed in situ in the atmosphere via the oxidation of gas-phase precursors (Pöschl, 2005). POC and precursors of SOC may stem from a vast variety of sources from both anthropogenic (e.g., coal combustion, vehicle emissions and cooking) and natural sources (e.g., biogenic emissions) (Carlton et al., 2009). These sources change over time and space, which makes source apportionment difficult.

Several techniques have been applied to quantify the emission sources of carbonaceous aerosols. Radiocarbon $\left({ }^{14} \mathrm{C}\right)$ measurements provide a powerful tool for unambiguously determining fossil and non-fossil sources of carbonaceous particles, since ${ }^{14} \mathrm{C}$ is completely depleted in fossil-fuel emissions due to its age (half-life 5730 years), whereas nonfossil carbon sources (e.g., biomass-burning, cooking or biogenic emissions) show a contemporary ${ }^{14} \mathrm{C}$ content (Szidat, 2009; Heal, 2014). Moreover, a better ${ }^{14} \mathrm{C}$-based source apportionment can be obtained when ${ }^{14} \mathrm{C}$ determinations are performed on OC and EC separately, since EC originates exclusively from combustion of biomass and fossil fuels (Szidat et al., 2006; Szidat, 2009; Bernardoni et al., 2013; Liu et al., 2013; Zhang et al., 2013). However, as both biogenic and biomass-burning OC contain ${ }^{14} \mathrm{C}$ on the contemporary level, it is still difficult to quantify the contribution from these two sources to $\mathrm{OC}$ by ${ }^{14} \mathrm{C}$ measurements alone. When these are combined with OC/EC and organic marker measurements, the primary and secondary origins of the fossil and non-fossil fractions can be identified (Szidat et al., 2006; Szidat et al., 2007; Szidat et al., 2009; Minguillón et al., 2011; Yttri et al., 2011). In particular, levoglucosan, a thermal degradation product of cellulose combustion, can be used as a molecular marker to identify primary biomass-burning emissions ( $\mathrm{Si}$ moneit et al., 1999; Puxbaum et al., 2007; Viana et al., 2013).

During January 2013, the severe problem of air pollution in China became a worldwide concern as extremely high concentrations of $24 \mathrm{~h} \mathrm{PM}_{2.5}$ (i.e., often $>100 \mu \mathrm{m} \mathrm{m}^{-3}$ ) were reported in several large cities, affecting $\sim 1.3$ million $\mathrm{km}^{2}$ and $\sim 800$ million people. To investigate sources and formation mechanisms of fine carbonaceous aerosols from this high-pollution episode across China, an intensive field experiment was carried out in the four large cities Xi'an, Beijing, Shanghai and Guangzhou, each of them located in different climatic regions, i.e., the central-northwest region, BeijingTianjin region, Yangtze River Delta region and Pearl River Delta region, respectively. These measurements were used in conjunction with Latin hypercube sampling (LHS) (Gelencsér et al., 2007) to elucidate the origins of the carbonaceous aerosol during the haze event.

\section{Methods}

\subsection{Sampling}

Measurement sites are located in Xi'an, Beijing, Shanghai and Guangzhou, the representative cities of the centralnorthwest region, Beijing-Tianjin region, Yangtze River Delta region and Pearl River Delta region, respectively. In these regions, haze events frequently occur during winter, when weather conditions trap pollutants over the plain. Detailed descriptions of the sampling sites are given in Table 1. In each city, $24 \mathrm{~h}$ integrated $\mathrm{PM}_{2.5}$ samples were collected on pre-baked quartz filters using high-volume samplers at a flow rate of $\sim 1.05 \mathrm{~m}^{3} \mathrm{~min}^{-1}$ from 5 to 25 January 2013. The sampling sites are located within campuses of universities or at research centers, $>100 \mathrm{~m}$ away from local sources such as major roadways, industry or domestic sources. At each sampling site, one field blank sample was collected and analyzed. The results reported here are corrected for corresponding field blanks (Cao et al., 2013). All samples collected were stored at $-20^{\circ} \mathrm{C}$ before analysis. The $\mathrm{PM}_{2.5}$ mass on each filter was gravimetrically measured using a temperature- and relative-humidity-controlled microbalance. 
Table 1. Sampling information.

\begin{tabular}{lllc}
\hline City & $\begin{array}{l}\text { City description } \\
\text { (population) }\end{array}$ & Location & Temperature $\left({ }^{\circ} \mathrm{C}\right)$ \\
\hline $\begin{array}{l}\text { Xi'an (XA), } \\
\text { northern China }\end{array}$ & $\begin{array}{l}\text { The largest city in Guanzhong city cluster } \\
(8.6 \text { million) }\end{array}$ & $34.2^{\circ} \mathrm{N}, 108.9^{\circ} \mathrm{E}$ & -12 to -1 \\
\hline $\begin{array}{l}\text { Beijing (BJ), } \\
\text { northern China }\end{array}$ & $\begin{array}{l}\text { Capital of China, developed megacity in } \\
\text { Beijing-Tianjin-Hebei city cluster } \\
(20.7 \text { million) }\end{array}$ & $39.9^{\circ} \mathrm{N}, 116.4^{\circ} \mathrm{E}$ & -9 to -1 \\
\hline $\begin{array}{l}\text { Shanghai (SH), } \\
\text { southern China }\end{array}$ & $\begin{array}{l}\text { Industrial and commercial megacity in } \\
\text { Yangtze River Delta region city cluster } \\
(24 \text { million })\end{array}$ & $31.3^{\circ} \mathrm{N}, 121.5^{\circ} \mathrm{E}$ & $2-11$ \\
\hline $\begin{array}{l}\text { Guangzhou (GZ), } \\
\text { southern China }\end{array}$ & $\begin{array}{l}\text { Industrial and commercial megacity in } \\
\text { Pearl River Delta region city cluster } \\
(12.7 \text { million })\end{array}$ & $23.1^{\circ} \mathrm{N}, 113.4^{\circ} \mathrm{E}$ & $7-19$ \\
\hline
\end{tabular}

\subsection{Thermal-optical carbon analysis}

A $1.0 \mathrm{~cm}^{2}$ punch from the filter samples is taken for the analysis of the OC and EC mass concentrations by the EUSAAR_2 thermal-optical transmission protocol (Cavalli et al., 2010). The replicate analysis of samples $(n=6)$ showed a good analytical precision with relative standard deviations of $4.8,9.1$ and $5.0 \%$ for OC, EC and TC, respectively. The average field blank of $\mathrm{OC}$ was $2.0 \pm 1.0 \mu \mathrm{g} \mathrm{cm}^{-2}$ (equivalent to $\sim 0.5 \mu \mathrm{g} \mathrm{m}^{-3}$ ), which was subtracted from the measured OC concentrations. A corresponding EC blank was not detectable.

\section{$2.3 \quad{ }^{14} \mathrm{C}$ analysis of the carbonaceous fractions}

Six filters were selected per sampling site for ${ }^{14} \mathrm{C}$ analysis: three from days with a very high PM loading and three representing an average loading, which are described in Table S1 in the Supplement. A thermo-optical OC/EC analyzer (Model4L, Sunset Laboratory Inc, USA) equipped with a non-dispersive infrared detector is used for the isolation of different carbon fractions for subsequent ${ }^{14} \mathrm{C}$ measurements using the four-step thermo-optical protocol Swiss_4S. The method is described in detail elsewhere (Zhang et al., 2012). For EC isolation, filter samples are first treated by water extraction to remove water-soluble $\mathrm{OC}$ to minimize the positive artifact from OC charring to the ${ }^{14} \mathrm{C}$ result of EC. To remove both non-refractory and refractory OC fractions, the water-extracted filters are then combusted or heated in the following three steps: step one in an oxidizing atmosphere $\left(\mathrm{O}_{2}, 99.9995 \%\right)$ at $375^{\circ} \mathrm{C}$ for $150 \mathrm{~s}$; step two in $\mathrm{O}_{2}$ at $475^{\circ} \mathrm{C}$ for $180 \mathrm{~s}$; step three in helium, at $450^{\circ} \mathrm{C}$ for $180 \mathrm{~s}$ and then at $650^{\circ} \mathrm{C}$ for $180 \mathrm{~s}$. Finally, EC is isolated by the combustion of the remaining carbonaceous material at $760^{\circ} \mathrm{C}$ within $150 \mathrm{~s}$ in $\mathrm{O}_{2}$. This method is optimized to minimize a possible negative EC artifact due to losses of the least refractory EC in the OC removal steps prior to EC collection. The aforementioned negative artifact due to premature EC loss during a harsh OC removal procedure (e.g., combustion of samples at $375^{\circ} \mathrm{C}$ for $4 \mathrm{~h}$ or longer) before $\mathrm{EC}$ isolation may underestimate biomass-burning EC contribution by up to $\sim 70 \%$, if only small amounts of EC are recovered (Zhang et al., 2012). The EC recovery for ${ }^{14} \mathrm{C}$ measurement in this work is $78 \pm 10 \%$. A bias from underestimation of biomass-burning EC caused by the EC loss of $22 \pm 10 \%$ is corrected using the approach described by Zhang et al. (2012). For TC samples, the filters are combusted using the whole Swiss_4S protocol without OC/EC separation. After the combustion/separation of the desired carbonaceous aerosol fractions (i.e., TC or EC), the resulting $\mathrm{CO}_{2}$ is trapped cryogenically and sealed in glass ampoules for ${ }^{14} \mathrm{C}$ measurement, which is conducted by the tabletop accelerator mass spectrometry (AMS) system MICADAS using a gas ion source (Wacker et al., 2013) at the Laboratory for the Analysis of Radiocarbon with AMS, University of Bern, Switzerland (Szidat et al., 2014). ${ }^{14} \mathrm{C}$ results are expressed as fractions of modern $\left(f_{\mathrm{M}}\right)$, i.e., the fraction of the ${ }^{14} \mathrm{C} /{ }^{12} \mathrm{C}$ ratio of the sample related to the isotopic ratio of the reference year 1950 (Stuiver and Polach, 1977). These data are then corrected for ${ }^{14} \mathrm{C}$ decay during the period between 1950 and 2013, i.e., the year of measurement. The uncertainties of $f_{\mathrm{M}}(\mathrm{EC})$ and $f_{\mathrm{M}}(\mathrm{TC})$ are $<5 \%$ and $<2 \%$, respectively. ${ }^{14} \mathrm{C}$ results in $\mathrm{OC}\left(f_{\mathrm{M}}(\mathrm{OC})\right)$ are not measured directly but calculated by

$f_{\mathrm{M}}(\mathrm{OC})=\frac{\mathrm{TC} \times f_{\mathrm{M}}(\mathrm{TC})-\mathrm{EC} \times f_{\mathrm{M}}(\mathrm{EC})}{\mathrm{OC}}$.

The uncertainty of $f_{\mathrm{M}}(\mathrm{OC})$ estimated by this approach is on average $8 \%$, obtained from an error propagation and including all the individual uncertainties of the $f_{\mathrm{M}}(\mathrm{TC})(2 \%)$, $f_{\mathrm{M}}(\mathrm{EC})(5 \%)$, TC $(8 \%)$ and $\mathrm{EC}(25 \%)$. No blank corrections are made for determination of ${ }^{14} \mathrm{C}$ because the different carbonaceous fractions contributions from field blanks are all less than $2 \%$ and thus can be neglected. 
Table 2. Central values with low and high limits of input parameters for source apportionment using LHS.

\begin{tabular}{lccc}
\hline Parameter & Low & Central & High \\
\hline EC error factor $^{\mathrm{a}}$ & 0.75 & $\mathrm{~b}$ & 1.25 \\
${\text { (EC/OC })_{\mathrm{bb}}}^{\mathrm{E}}$ & 0.07 & 0.11 & 0.20 \\
(lev/OC $_{\mathrm{bb}}$ & 0.10 & 0.22 & 0.30 \\
$(\mathrm{EC} / \mathrm{OC})_{\text {pri, cc }}$ & 0.32 & 0.44 & 0.62 \\
$(\mathrm{EC} / \mathrm{OC})_{\text {pri, ve }}$ & 0.8 & $\mathrm{~b}$ & 2.1 \\
$p$ & 0 & $\mathrm{~b}$ & 0.7 \\
$f_{\mathrm{M}}(\mathrm{bb})$ & 1.05 & 1.10 & 1.15 \\
$f_{\mathrm{M}}(\mathrm{nf})$ & 1.03 & $\mathrm{~b}$ & $\mathrm{c}$ \\
\hline
\end{tabular}

${ }^{\mathrm{a}} \mathrm{EC}$ values multiplied by given factor.

$\mathrm{b}$ The average of low and high limits is used.

${ }^{\mathrm{c}} f_{\mathrm{M}}(\mathrm{nf})$ constrained to be $<f_{\mathrm{M}}(\mathrm{bb})$

\subsection{Anhydrosugars and water-soluble potassium measurements}

The anhydrosugars (levoglucosan and mannosan) are measured by a recently developed in situ derivatization/thermal desorption gas chromatography-mass spectrometry method (IDTD-GC-MS) (Schnelle-Kreis et al., 2005; Orasche et al., 2011). In brief, the filter punches are placed into glass liners suitable for an automated thermal desorption unit. Isotope-labeled standard compounds are spiked onto the filter surface to account for matrix influences for quantification. Derivatization is performed on the filter by adding the liquid reagent $N$-methyl- $N$-(trimethylsilyl) trifluoroacetamide (MSTFA, Macherey-Nagel, Germany). During the 16 min desorption time, an in situ derivatization with gaseous MSTFA is carried out to quantitatively silylate polar organic compounds and optimize the automated desorption process. Derivatized and desorbed molecules are first trapped on a pre-column before being separated by gas chromatography (BPX-5 capillary column, SGE, Australia). The detection and quantification of compounds are carried out on a Pegasus III time-of-flight mass spectrometer (TOF-MS) using the ChromaTOF software package (LECO, St. Joseph, MI).

Concentrations of water-soluble potassium $\left(\mathrm{K}^{+}\right)$and other ions are analyzed with ion chromatography (850 Professional IC, Metrohm, Switzerland) after the leaching of a $1.0 \mathrm{~cm}^{2}$ punch of the filter samples in an ultrasonic bath with $50 \mathrm{~g}$ of ultrapure water (18.2 $\mathrm{M} \Omega$ quality) at $40^{\circ} \mathrm{C}$ for $30 \mathrm{~min}$.

\subsection{Source apportionment methodology}

Source apportionment results are obtained by Latin hypercube sampling using the data set from the measured OC, EC and levoglucosan mass concentrations, estimated emission ratios and ${ }^{14} \mathrm{C}$ contents of $\mathrm{OC}$ and $\mathrm{EC}$. The LHS methodology, which is comparable to the Monte Carlo simulation, was first proposed by Gelencsér et al. (2007) and later applied to many European sites (e.g., Szidat et al., 2009; Yttri et al., 2011; Gilardoni et al., 2011 and Genberg et al., 2011). In brief, central values with low and high limits are associated with all uncertain input parameters (Table 2). Due to the lack for information on the input factors, parameters are assigned equally between the low limit and the central value and between the central value and the high limit. All combinations of parameters are included in frequency distributions of possible solutions except those producing negative values. The approach used here is slightly modified compared to previous studies and briefly summarized in the following.

$\mathrm{EC}$ arises from biomass burning $\left(\mathrm{EC}_{\mathrm{bb}}\right)$ and fossil-fuel combustion $\left(\mathrm{EC}_{\mathrm{f}}\right)$ :

$\mathrm{EC}=\mathrm{EC}_{\mathrm{f}}+\mathrm{EC}_{\mathrm{bb}}$.

$\mathrm{EC}_{\mathrm{bb}}$ is calculated from the $\mathrm{EC}$ mass concentration, $f_{\mathrm{M}}(\mathrm{EC})$, and a reference value of biomass-burning EC (i.e., fraction of modern in EC emitted from biomass-burning sources, $\left.f_{\mathrm{M}}(\mathrm{bb})\right)$ :

$\mathrm{EC}_{\mathrm{bb}}=\mathrm{EC} \times \frac{f_{\mathrm{M}}(\mathrm{EC})}{f_{\mathrm{M}}(\mathrm{bb})}$.

Analogously, $\mathrm{OC}$ is divided into two sub-fractions, $\mathrm{OC}$ from fossil-fuel $\left(\mathrm{OC}_{\mathrm{f}}\right)$ and non-fossil emissions $\left(\mathrm{OC}_{\mathrm{nf}}\right)$. To account for the thermonuclear weapon tests of the late 1950s and early $1960 \mathrm{~s}, \mathrm{OC}_{\mathrm{nf}}$ is calculated from the OC mass concentration, $f_{\mathrm{M}}(\mathrm{OC})$, and a ${ }^{14} \mathrm{C}$ reference value of non-fossil emissions (i.e., fraction of modern in $\mathrm{OC}$ emitted from nonfossil sources, $f_{\mathrm{M}}(\mathrm{nf})$ ):

$\mathrm{OC}=\mathrm{OC}_{\mathrm{f}}+\mathrm{OC}_{\mathrm{nf}}$,

$\mathrm{OC}_{\mathrm{nf}}=\mathrm{OC} \times \frac{f_{\mathrm{M}}(\mathrm{OC})}{f_{\mathrm{M}}(\mathrm{nf})}$.

In addition to this straightforward $\mathrm{OC}$ distinction, $\mathrm{OC}_{\mathrm{f}}$ and $\mathrm{OC}_{\mathrm{nf}}$ are semi-quantitatively classified into additional subfractions. On the one hand, $\mathrm{OC}_{\mathrm{f}}$ is split into primary and secondary $\mathrm{OC}$ from fossil sources, i.e., $\mathrm{OC}_{\mathrm{pri}, \mathrm{f}}$ and $\mathrm{OC}_{\mathrm{sec}, \mathrm{f}}$, respectively:

$\mathrm{OC}_{\mathrm{f}}=\mathrm{OC}_{\text {pri, } \mathrm{f}}+\mathrm{OC}_{\mathrm{sec}, \mathrm{f}}$.

$\mathrm{OC}_{\mathrm{pri}}, \mathrm{f}$ is determined from $\mathrm{EC}_{\mathrm{f}}$ and a primary $\mathrm{OC} / \mathrm{EC}$ emission ratio for fossil-fuel combustion, i.e., $(\mathrm{OC} / \mathrm{EC})_{\mathrm{pri}}$, :

$\mathrm{OC}_{\mathrm{pri}, \mathrm{f}}=\mathrm{EC}_{\mathrm{f}} \times\left(\frac{\mathrm{OC}}{\mathrm{EC}}\right)_{\text {pri, } \mathrm{f}}$.

As fossil-fuel combustion in China is almost exclusively from coal combustion and vehicle emissions, $(\mathrm{OC} / \mathrm{EC})_{\mathrm{pri}, \mathrm{f}}$ can be determined as

$$
\begin{aligned}
\left(\frac{\mathrm{OC}}{\mathrm{EC}}\right)_{\mathrm{pri}, \mathrm{f}} & =p \times\left(\frac{\mathrm{OC}}{\mathrm{EC}}\right)_{\mathrm{pri}, \mathrm{cc}}+(1-p) \\
& \times\left(\frac{\mathrm{OC}}{\mathrm{EC}}\right)_{\mathrm{pri}, \mathrm{ve}},
\end{aligned}
$$

where $p$ is a percentage of coal combustion in total fossil emissions and $(\mathrm{OC} / \mathrm{EC})_{\mathrm{pri}, \mathrm{cc}}$ and $(\mathrm{OC} / \mathrm{EC})_{\mathrm{pri}}$, cc are primary 
OC/EC ratios for coal combustion (cc) and vehicle emissions (ve), respectively.

This strategy can only be applied to $\mathrm{OC}_{\mathrm{nf}}$ after some modification because its primary $\mathrm{OC} / \mathrm{EC}$ emission ratio is far too uncertain for a general split of non-fossil OC into primary and secondary formation. Alternatively, $\mathrm{OC}_{\mathrm{nf}}$ is subdivided into primary biomass-burning $\left(\mathrm{OC}_{\mathrm{bb}}\right)$ and all the other nonfossil sources $\left(\mathrm{OC}_{\text {other, }}\right.$ ) :

$\mathrm{OC}_{\mathrm{nf}}=\mathrm{OC}_{\mathrm{bb}}+\mathrm{OC}_{\mathrm{other}, \mathrm{nf}}$

$\mathrm{OC}_{\mathrm{other}} \mathrm{nf}$ includes all non-fossil sources other than $\mathrm{OC}_{\mathrm{bb}}$, thus mainly representing primary and secondary biogenic OC, urban non-fossil contributions (e.g., from cooking or frying) and SOC from biomass burning; due to cholesterol concentrations below the limit of detection in all samples, however, contributions of cooking and/or frying to $\mathrm{OC}_{\mathrm{other}} \mathrm{nf}$ can be neglected. $\mathrm{OC}_{\mathrm{bb}}$ is calculated by two alternative "marker-to-OC" methods using either $\mathrm{EC}_{\mathrm{bb}}$ or levoglucosan (lev) as the biomass-burning marker with corresponding primary marker-to-OC emission ratios (Eqs. 10 and 11).

$\begin{aligned} \mathrm{OC}_{\mathrm{bb}} & =\frac{\mathrm{EC}_{\mathrm{bb}}}{\left(\frac{\mathrm{EC}}{\mathrm{OC}}\right)_{\mathrm{bb}}} \\ \mathrm{OC}_{\mathrm{bb}} & =\frac{\mathrm{lev}}{\left(\frac{\mathrm{lev}}{\mathrm{OC}}\right)_{\mathrm{bb}}}\end{aligned}$

The overlapping results of both calculations are considered as probable solutions for $\mathrm{OC}_{\mathrm{bb}}$. The consistency of $\mathrm{EC}_{\mathrm{bb}}$ and levoglucosan data is shown below in Fig. 4.

Extensive discussion of the selection of the used input parameters can be found in earlier studies conducted in Europe (e.g., Gelencsér et al., 2007; Szidat et al., 2009; Yttri et al., 2011; Gilardoni et al., 2011; Genberg et al., 2011). However, due to different conditions in this study, the input values have to be adapted (Table 2):

1. To correct for the ${ }^{14} \mathrm{C}$ bomb peak, the reference values of $f_{\mathrm{M}}$ for biomass-burning and non-fossil sources, $f_{\mathrm{M}}(\mathrm{bb})$ and $f_{\mathrm{M}}(\mathrm{nf})$, respectively, are adapted to the sampling year 2013. $f_{\mathrm{M}}(\mathrm{bb})$ is estimated as $1.10 \pm 0.05$ using a tree growth model as described in Mohn et al. (2008). The low limit of $f_{\mathrm{M}}(\mathrm{nf})$ is 1.03 , which is equal to the $f_{\mathrm{M}}$ of $\mathrm{CO}_{2}$ in the atmosphere (Levin et al., 2010), and the high limit of $f_{\mathrm{M}}(\mathrm{nf})$ is $f_{\mathrm{M}}(\mathrm{bb})$; the central value is the average of both.

2. Literature data indicate that emission ratios depend on fuel types and combustion conditions as well as specific measurement techniques, e.g., for EC mass (Fine et al., 2004; Puxbaum et al., 2007). A range of 0.070.20 and $0.10-0.30$ is used as the low-to-high values for $(\mathrm{lev} / \mathrm{OC})_{\mathrm{bb}}$ and $(\mathrm{EC} / \mathrm{OC})_{\mathrm{bb}}$, respectively, covering most of the variation in the measurements and the range used in previous studies (e.g., Gelencser et al.,
2007; Genberg et al., 2011; Szidat et al., 2009; Yttri et al., 2011). Zhang et al. (2007b) reported an average (lev/OC) bb ratio of 0.082 for the main types of Chinese cereal straw (rice, wheat and corn) based on combustion chamber experiments. As cereal straw is one of the most abundant biomasses burned in China, the above ratio (0.082) was used to estimate biomass-burning contribution to OC in Beijing (Zhang et al., 2008) and Hong Kong (Sang et al., 2011). However, this ratio is lower than that $(0.14)$ obtained from the combustion of hardwood in fireplaces and stoves in the US (Fine et al., 2004), which was applied to estimate the contribution of biomass burning to OC at background sites in Europe (Gelencsér et al., 2007; Puxbaum et al., 2007; Schmidl et al., 2008). Considering both main biomass types (i.e., mainly cereal straw but also hardwood burning) (see Sect. 3.2.3), the central value for (lev/OC) bb of 0.11 is used in this study. Based on emission factors for primary particulate emissions in China (Zhang et al., 2007), the central value for $(\mathrm{EC} / \mathrm{OC})_{\mathrm{bb}}$ of 0.22 is chosen.

3. $(\mathrm{EC} / \mathrm{OC})_{\text {pri, ve }}$ is determined for emissions from traffic as $0.8-2.1$ with the central value of 1.45 , which is taken from composite profiles from tunnel experiments in $\mathrm{Eu}-$ rope (Gelencsér et al., 2007); the range of this ratio also covers many tunnel studies conducted in China (Huang et al., 2006; He et al., 2008). (EC/ OC) pri,cc ranges for emissions of coal burning in China from 0.32 to 0.62 , depending on the share of briquette and chunk bituminous coal with a central value of 0.44 for the average coal inventory (Zhi et al., 2008).

4. In many urban sites such as Barcelona (Minguillón et al., 2011), Zurich (Szidat et al., 2006) and Pasadena (Zotter et al., 2014), EC $\mathrm{f}_{\mathrm{f}}$ was almost exclusively attributed to vehicle emissions. However, coal combustion in China is also considered to be an important contributor to EC emissions in winter from both field studies (Cao et al., 2011b) and inventory estimations (Cao et al., 2011a). Recently, Huang et al. (2014) reported relative contributions of coal combustion to total fossil emissions (i.e., $p$ in the Eq. 8) ranges from 0.16 to 0.80 in Chinese aerosols. In this study, $p$ is assigned as 0 0.7 with the central value of 0.35 . It should be noted that for the regions with negligible coal combustion, $p$ can be directly assigned as 0 to simplify this approach. In such a case, $(\mathrm{EC} / \mathrm{OC})_{\text {pri, } \mathrm{f}}$ is equal to $(\mathrm{EC} / \mathrm{OC})_{\mathrm{pri}}$, ve.

To evaluate uncertainties of the quantification of source contributions, the LHS method is implemented to generate 3000 random sets of variables (Gelencsér et al., 2007). A few simulations producing negative solutions are excluded, the median value from the remaining simulations is considered as the best estimate (see Sect. 3.2) and the 10th and 90th percentiles of the solutions are treated as uncertainties. These 

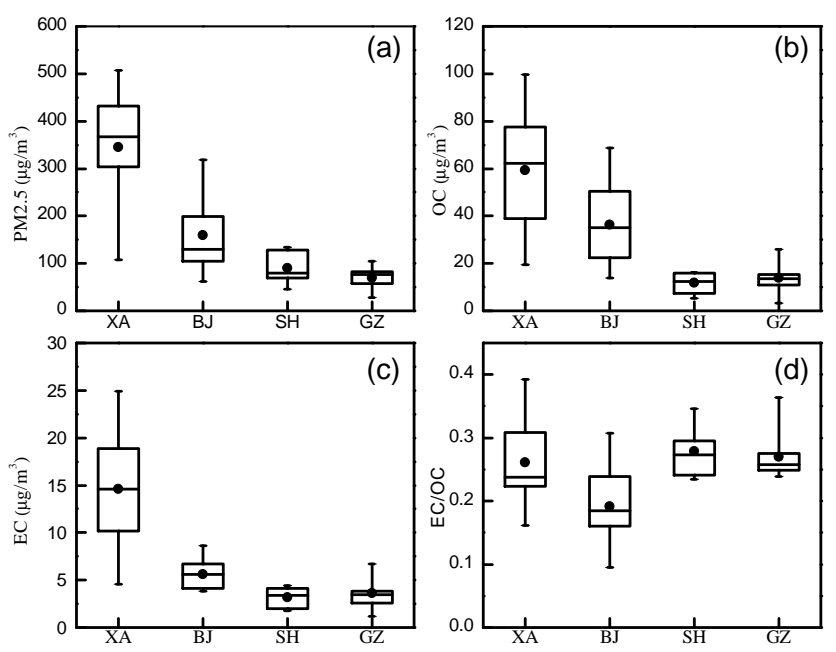

Figure 1. Box-and-whisker plots of mass concentrations of $\mathrm{PM}_{2.5}$ (a), OC (b) and EC (c) and EC/OC ratios (d) for samples collected in Xi'an (XA), Beijing (BJ), Shanghai (SH) and Guangzhou (GZ) during the winter of 2013. The box represents the 25th (lower line), 50th (middle line) and 75th (top line) percentiles; the solid dots within the box represent the mean values; the end of the vertical bars represents the 10th (below the box) and 90th (above the box) percentiles.

uncertainties typically amount to 13 and $10 \%$ for the separation of $\mathrm{EC}$ into $\mathrm{EC}_{\mathrm{f}}$ and $\mathrm{EC}_{\mathrm{bb}}$ and for $\mathrm{OC}$ into $\mathrm{OC}_{\mathrm{f}}$ and $\mathrm{OC}_{\mathrm{nf}}$, respectively. The uncertainties are higher for the further source apportionment of $\mathrm{OC}$ (on the average 25, 20, 20 and $25 \%$ for $\mathrm{OC}_{\mathrm{pri}, \mathrm{f}}, \mathrm{OC}_{\mathrm{sec}, \mathrm{f}}, \mathrm{OC}_{\mathrm{bb}}$ and $\mathrm{OC}_{\mathrm{other}, \mathrm{nf}}$, respectively). The ${ }^{14} \mathrm{C}$ analysis performed on the $\mathrm{EC}$ fraction directly enables a more reliable quantification of fossil and biomass-burning EC compared to those results obtained by many previous studies (e.g., Gelencser et al., 2007; Yttri et al., 2011; Genberg et al., 2011), in which ${ }^{14} \mathrm{C}$ analysis was only conducted on TC samples. The results of the sensitivity analysis and the determination of the uncertainties will be discussed further in Sect. 3.2.4. The comparison of the ${ }^{14} \mathrm{C}$ approach with other organic makers (see Sect. 3.2.3) as well as with the source apportionment results from positive matrix factorization (Paatero and Tapper, 1994) using the multilinear engine (ME-2) algorithm (Paatero and Hopke, 2009) (see Sect. 3.3.3) will provide additional measures to evaluate the model performance.

\section{Results and discussions}

\section{1 $\quad \mathrm{PM}_{2.5}$ and carbonaceous aerosols mass concentrations}

The box-and-whisker plots (Fig. 1) show the concentrations of $\mathrm{PM}_{2.5}$, OC and $\mathrm{EC}$ and EC-to-OC ratios (EC/OC) in the four Chinese cities. The average $\mathrm{PM}_{2.5}$ mass concentrations at the Xi'an, Beijing, Shanghai and Guangzhou sampling sites during the sampling periods were $345 \pm 125 \mu \mathrm{g} \mathrm{m}^{-3}$, $158 \pm 81 \mu \mathrm{g} \mathrm{m}^{-3}, 90 \pm 31 \mu \mathrm{g} \mathrm{m}^{-3}$ and $68 \pm 23 \mu \mathrm{g} \mathrm{m}^{-3}$, respectively. Despite large variations in the $\mathrm{PM}_{2.5}$ concentrations within each site, their concentrations were always higher in Xi' an and Beijing compared to those in Shanghai and Guangzhou, reflecting a poorer air quality in northern China. Extremely high $\mathrm{PM}_{2.5}$ concentrations were observed for several days during the sampling period. The highest $24 \mathrm{~h}$ average $\mathrm{PM}_{2.5}$ value (134-517 $\mu \mathrm{g} \mathrm{m}^{-3}$ ) was 5-20 times higher than the WHO guideline for $24 \mathrm{~h} \mathrm{PM}_{2.5}\left(25 \mu \mathrm{g} \mathrm{m}^{-3}\right.$; WHO, 2006). Only $3 \%$ of $\mathrm{PM}_{2.5}$ mass values were below this guideline value, indicating a very high negative impact on human health in all studied cities.

OC and EC concentrations showed similar spatial distributions as the $\mathrm{PM}_{2.5}$ mass in the following order: Xi' an > Beijing > Shanghai > Guangzhou. Given that average temperatures during the sampling period were $10-20^{\circ} \mathrm{C}$ lower in Xi' an and Beijing than in Shanghai and Guangzhou, the high concentrations of carbonaceous species in northern cities could be due to enhanced fuel consumption for heating activities (Weilenmann et al., 2009; Nordin et al., 2013). The EC/OC ratios were comparable for Xi' an, Shanghai and Guangzhou but considerably lower at Beijing.

We also compared the data of OC, EC and EC/OC from heavily polluted days with moderately polluted days, which were selected from the samples with the highest and average PM loading, respectively (Table 3). ${ }^{14} \mathrm{C}$ measurements were also performed on these samples (Sect. 2.3), and a detailed source apportionment result will be presented in Sect. 3.2. The $\mathrm{PM}_{2.5}$, OC and EC mass concentrations on heavily polluted days were mostly $>2$ times higher than those on moderately polluted days at the four sites. On the heavily polluted days, the EC/OC ratios significantly decreased by 29 and $43 \%$ in the northern cities of Xi' an and Beijing, respectively, whereas they slightly increased in Shanghai and Guangzhou by 13 and $16 \%$, respectively. The meteorological conditions during the polluted period was characterized by low wind speed, but the $\mathrm{PM}_{2.5}$, OC and EC mass concentrations were not significantly correlated with the temperature and relative humidity.

\subsection{Best estimate of source apportionment results}

\subsubsection{Fossil and biomass-burning EC}

Figure 2 shows the source apportionment results of EC. The concentration of $\mathrm{EC}$ from fossil-fuel sources $\left(\mathrm{EC}_{\mathrm{f}}\right)$ ranged from 0.61 to $16.8 \mu \mathrm{g} \mathrm{m}^{-3}$, whereas the corresponding range for $\mathrm{EC}$ from biomass burning $\left(\mathrm{EC}_{\mathrm{bb}}\right)$ was 0.57 to $4.71 \mu \mathrm{g} \mathrm{m}^{-3}$. $\mathrm{EC}_{\mathrm{f}}$ values were on average 3 times as high as $\mathrm{EC}_{\mathrm{bb}}$, corresponding to a mean fraction of $\mathrm{EC}_{\mathrm{f}}$ to total $\mathrm{EC}$ of 0.75. The highest concentrations of $\mathrm{EC}_{\mathrm{bb}}$ and $\mathrm{EC}_{\mathrm{f}}$ were observed in Xi' an, followed by Beijing and the two southern sites Shanghai and Guangzhou. 
Table 3. Averages and SDs of the mass concentrations $\left(\mu \mathrm{g} \mathrm{m}^{-3}\right)$ of $\mathrm{PM}_{2.5}$, OC, EC and EC/OC ratios and fractions of modern $\left(f_{\mathrm{M}}\right)$ of OC and EC for samples collected on moderately polluted days (MPD) $(n=3$ for each city) and heavily polluted days (HPD) ( $n=3$ for each city) in Xi' an, Beijing, Shanghai and Guangzhou.

\begin{tabular}{lllllll}
\hline & $\mathrm{PM}_{2.5}$ & $\mathrm{OC}$ & $\mathrm{EC}$ & $\mathrm{EC} / \mathrm{OC}$ & $f_{\mathrm{M}}(\mathrm{OC})$ & $f_{\mathrm{M}}(\mathrm{EC})$ \\
\hline Xi'an & & & & & & \\
MPD & $136 \pm 27$ & $24.6 \pm 6.3$ & $7.2 \pm 1.9$ & $0.30 \pm 0.07$ & $0.67 \pm 0.04$ & $0.25 \pm 0.03$ \\
$\mathrm{HPD}$ & $479 \pm 25$ & $94.2 \pm 6.8$ & $19.8 \pm 0.9$ & $0.21 \pm 0.02$ & $0.66 \pm 0.02$ & $0.24 \pm 0.02$ \\
HPD/MPD & $3.5 \pm 0.7$ & $3.8 \pm 1.0$ & $2.7 \pm 0.7$ & $0.71 \pm 0.17$ & $0.99 \pm 0.06$ & $0.98 \pm 0.16$ \\
\hline Beijing & & & & & & \\
MPD & $85 \pm 17$ & $18.0 \pm 3.4$ & $4.0 \pm 0.2$ & $0.23 \pm 0.06$ & $0.49 \pm 0.03$ & $0.30 \pm 0.02$ \\
HPD & $266 \pm 49$ & $59.2 \pm 7.5$ & $7.7 \pm 0.9$ & $0.13 \pm 0.03$ & $0.40 \pm 0.01$ & $0.23 \pm 0.02$ \\
HPD/MPD & $3.1 \pm 0.9$ & $3.3 \pm 0.8$ & $1.9 \pm 0.2$ & $0.57 \pm 0.18$ & $0.82 \pm 0.06$ & $0.79 \pm 0.09$ \\
\hline Shanghai & & & & & & \\
MPD & $59 \pm 10$ & $6.2 \pm 1.0$ & $1.9 \pm 0.1$ & $0.31 \pm 0.04$ & $0.55 \pm 0.03$ & $0.21 \pm 0.02$ \\
HPD & $131 \pm 3$ & $15.6 \pm 0.5$ & $4.2 \pm 0.3$ & $0.27 \pm 0.02$ & $0.54 \pm 0.01$ & $0.24 \pm 0.04$ \\
HPD/MPD & $2.2 \pm 0.4$ & $2.5 \pm 0.4$ & $2.2 \pm 0.2$ & $0.87 \pm 0.12$ & $0.99 \pm 0.06$ & $1.13 \pm 0.22$ \\
\hline Guangzhou & & & & & & \\
MPD & $38 \pm 14$ & $5.4 \pm 2.3$ & $1.6 \pm 0.5$ & $0.31 \pm 0.04$ & $0.75 \pm 0.05$ & $0.48 \pm 0.05$ \\
HPD & $96 \pm 6$ & $23.3 \pm 2.2$ & $6.1 \pm 0.4$ & $0.26 \pm 0.01$ & $0.62 \pm 0.01$ & $0.22 \pm 0.02$ \\
HPD/MPD & $2.5 \pm 1.0$ & $4.3 \pm 1.9$ & $3.8 \pm 1.1$ & $0.84 \pm 0.11$ & $0.83 \pm 0.06$ & $0.47 \pm 0.06$ \\
\hline
\end{tabular}

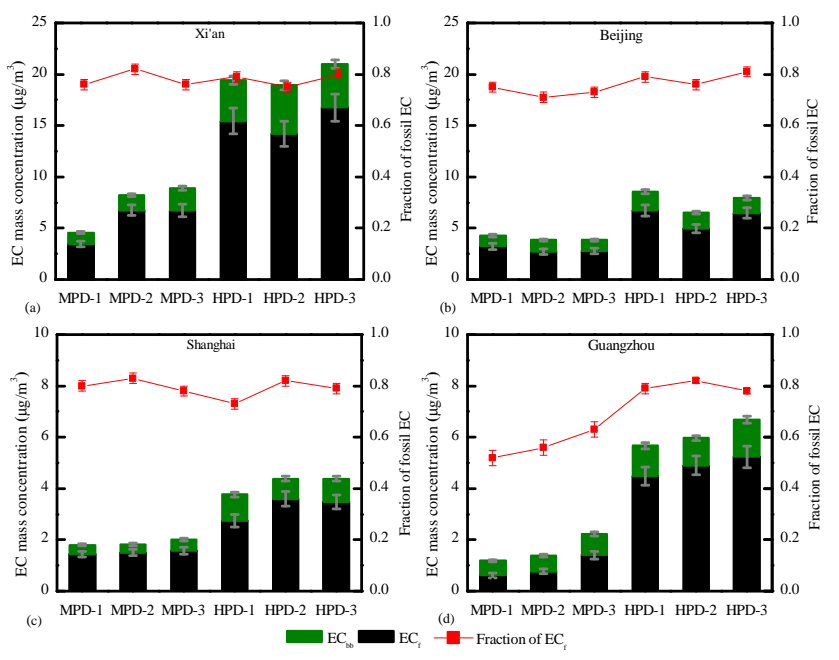

Figure 2. Mass concentrations $\left(\mu \mathrm{g} \mathrm{m}^{-3}\right)$ of EC from biomass burning and fossil-fuel combustion ( $\mathrm{EC}_{\mathrm{bb}}$ and $\mathrm{EC}_{\mathrm{f}}$, respectively) as well as fractions of fossil EC to total EC for aerosols samples in $\mathrm{Xi}$ 'an, Beijing, Shanghai and Guangzhou during moderately polluted days (MPD) and heavily polluted days (HPD). Note the different scaling for the northern and the southern cities.

Despite the wide range of EC concentrations, the fraction of $\mathrm{EC}_{\mathrm{f}}$ to total $\mathrm{EC}$ in Xi' an, Beijing and Shanghai was fairly constant, with average values of $78 \pm 3 \%, 76 \pm 4 \%$ and $79 \pm 4 \%$, respectively. This finding suggests that the increase of $\mathrm{EC}_{f}$ and $\mathrm{EC}_{\mathrm{bb}}$ emissions in the three cities on heavily polluted days is likely due to an equal enhancement of fossil-fuel and biomass-burning combustion emissions and the accumu- lation of these particulate pollutants. At Guangzhou, however, the $\mathrm{EC}_{\mathrm{f}}$ contribution was noticeably higher on the heavily (i.e., $80 \pm 2 \%$ ) polluted days compared to the moderately polluted days (i.e., $57 \pm 5 \%$ ), indicating that the increase of EC concentrations was caused by additional fossil-fuel emissions rather than by biomass burning. The measured fossil contributions to EC correspond to those previously reported at three city sites and two regional sites in China (Chen et al., 2013) but are higher than for the Maldives ( $31 \pm 5 \%)$, India $(36 \pm 3 \%)$ (Gustafsson et al., 2009) and a background site on the south Chinese island of Hainan (25-56\%) (Zhang et al., 2014a).

\subsubsection{Fossil and non-fossil OC}

The concentration of $\mathrm{OC}$ from fossil-fuel sources $\left(\mathrm{OC}_{\mathrm{f}}\right)$ ranged from 2.53 to $61.3 \mu \mathrm{g} \mathrm{m}^{-3}$, whereas the corresponding range for $\mathrm{OC}$ from non-fossil sources $\left(\mathrm{OC}_{\mathrm{nf}}\right)$ was 0.8 to $42.7 \mu \mathrm{g} \mathrm{m}^{-3}$ (Fig. 3). Similar to EC, the highest mean concentrations of both $\mathrm{OC}_{\mathrm{f}}$ and $\mathrm{OC}_{\mathrm{nf}}$ were observed at Xi'an and Beijing. The mean concentration of $\mathrm{OC}_{\mathrm{nf}}$ was higher than that of $\mathrm{OC}_{\mathrm{f}}$ for all sites except Beijing. $\mathrm{OC}_{\mathrm{f}}$ contributions (mean \pm standard deviation) to total OC were $37 \pm 3 \%$, $58 \pm 5 \%, 49 \pm 2 \%$ and $35 \pm 8 \%$ in Xi' an, Beijing, Shanghai and Guangzhou, respectively, which was lower than the corresponding $\mathrm{EC}_{\mathrm{f}}$ fraction to $\mathrm{EC}$ for all samples (Fig. 2). The high percentage of $\mathrm{OC}_{\mathrm{nf}}$ demonstrates that even in densely populated and urbanized areas of China, non-fossil sources are still a considerable and sometimes even dominant contributor of $\mathrm{OC}$, at least in winter. The large variability of the fraction of $\mathrm{OC}_{\mathrm{f}}$ to total $\mathrm{OC}$ among the dif- 


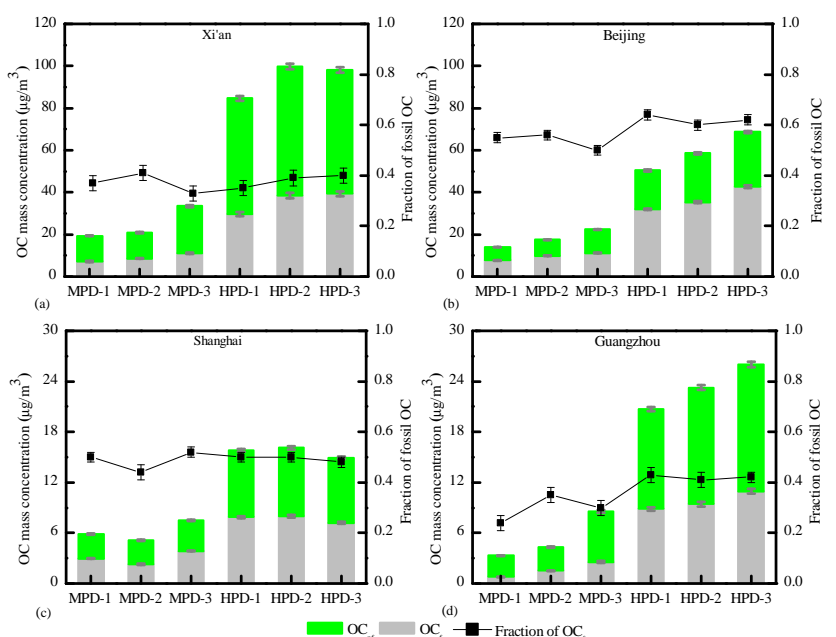

Figure 3. Mass concentrations $\left(\mu \mathrm{g} \mathrm{m}^{-3}\right.$ ) of OC from non-fossil and fossil emissions $\left(\mathrm{OC}_{\mathrm{nf}}\right.$ and $\mathrm{OC}_{\mathrm{f}}$, respectively) as well as fractions of fossil OC to total OC for samples collected in Xi'an, Beijing, Shanghai and Guangzhou during moderately polluted days (MPD) and heavily polluted days (HPD). Note the different scaling for the northern and the southern cities.

ferent cities furthermore reflects complex sources and formation processes of $\mathrm{OC}_{\mathrm{f}}$. In addition, the ratio of $\mathrm{EC}_{\mathrm{f}}$ to $\mathrm{OC}_{\mathrm{f}}\left((\mathrm{EC} / \mathrm{OC})_{\mathrm{f}}\right)$ in Beijing $(0.24 \pm 0.10)$ was substantially lower than in Xi' an $(0.53 \pm 0.15)$, Shanghai $(0.47 \pm 0.11)$ and Guangzhou $(0.56 \pm 0.11)$, which will be discussed below.

\subsubsection{Other biomass-burning markers}

Figure 4 shows that levoglucosan (lev) and mannosan (man) concentrations significantly correlated with $\mathrm{EC}_{\mathrm{bb}}$. Their correlation coefficients were 0.87 and 0.92 , respectively. In spite of different concentration levels, no significant differences were observed in the slopes among different cities for the different anhydrosugars or pollution levels. A possible explanation is that the burning conditions and fuel type were rather consistent during the sampling period for the four cities. Moreover, the regression slope $(0.41 \pm 0.03)$ of levoglucosan and $\mathrm{EC}_{\mathrm{bb}}$ obtained here was similar to that $(0.45)$ calculated by the ratio of the best estimates of lev/OC $(0.10)$ and EC/OC (0.22) using the LHS simulation (median values in Table 2), indicating that our assumption of LHS input parameters is reasonable. The average lev-to-man ratio was $27.7 \pm 8.47$ (ranging from 16.4 to 45.9 ), which is at the higher end of the reported ratios for crop-residue burning (ranging from 12.9 to 55.7 with a mean of $32.6 \pm 19.1$ ) and obviously higher than that for softwood $4.0 \pm 1.0$ (ranging from 2.5 to 5.8 with a mean of $4.0 \pm 1.0$ ) (Sang et al., 2013). However, the ratio is not significantly different from ratios reported for hardwood burning (ranging from 12.9 to 35.4 with a mean of $21.5 \pm 8.3$ ) (Sang et al., 2013).
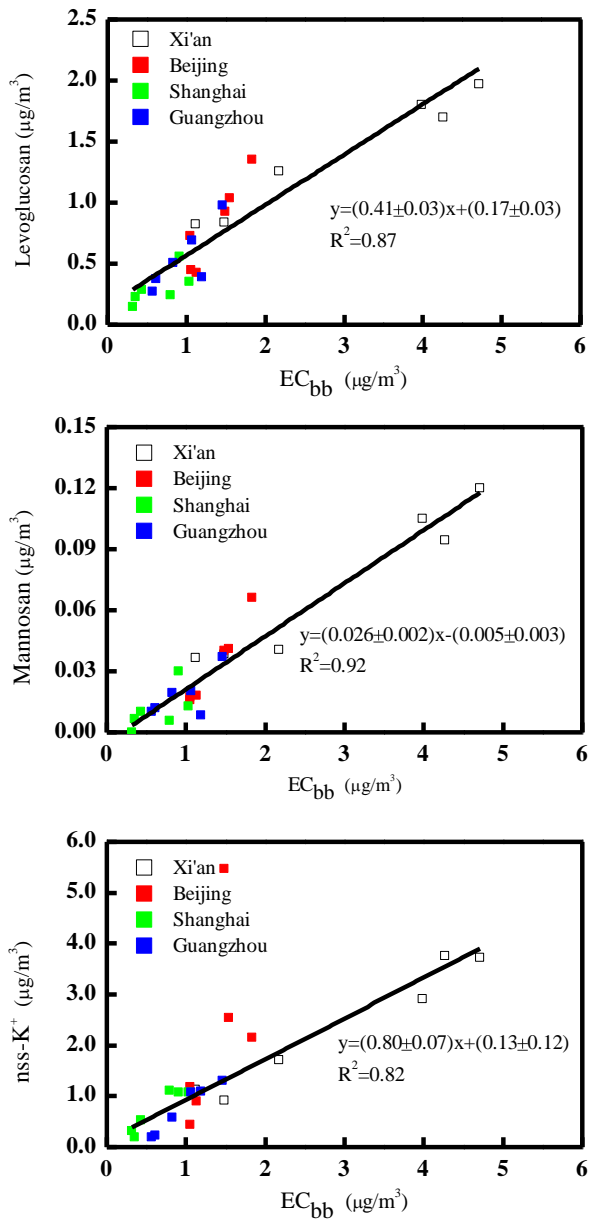

Figure 4. Scatter plots of concentrations of $\mathrm{EC}_{\mathrm{bb}}$ with levoglucosan (top), mannosan (middle) and non-sea-salt potassium (nss- $\mathrm{K}^{+}$, bottom).

Recently, Cheng et al. (2013) proposed that ratios of levoglucosan to another biomass-burning marker, non-sea-salt potassium (nss- $\mathrm{K}^{+}=\mathrm{K}^{+}-0.0355 \times \mathrm{Na}^{+}$; Lai et al., 2007), can be used to distinguish biomass burning from crop residue and wood. The average of lev-to-nss- $\mathrm{K}^{+}$in our study was $0.59 \pm 0.33$ (ranging from 0.17 to 1.56 with only two samples $>1$ ), which is comparable to the ratios for wheat straw $(0.10 \pm 0.00)$, corn straw $(0.21 \pm 0.08)$ and rice straw grown in Asia (0.62 \pm 0.32$)$ (Cheng et al., 2013). These ratios are much lower than those reported for hardwood $(23.96 \pm 1.82)$ (Cheng et al., 2013). With a combination of the lev-to-man and lev-to- $\mathrm{K}^{+}$ratios, it can be concluded that China's major source of biomass burning in winter is the combustion of crop residues. In addition, non-sea-salt potassium concentrations also show a very good correlation $\left(R^{2}=0.82\right)$ with $\mathrm{EC}_{\mathrm{bb}}$ for the four cities. This also confirms that the variability of burning conditions and biomass types was rather small during winter 2013 in different regions of China. 
Table 4. Average TC concentration and relative contribution to TC from OC and EC source categories (see in Fig. 6) for samples collected in Xi' an (XA), Beijing (BJ), Shanghai (SH) and Guangzhou (GZ) during the moderately polluted days (MPD) and the heavily polluted days (HPD). Distributions from Latin hypercube sampling are given as medians and as the 10th and 90th percentiles (in parentheses). See Table S2 for an alternative solution for Beijing assuming a higher contribution of coal combustion as explained below in Sect. 3.3.3.

\begin{tabular}{llllllll}
\hline $\begin{array}{l}\text { Sample } \\
\text { code }\end{array}$ & $\begin{array}{l}\mathrm{TC} \\
\mu \mathrm{g} \mathrm{m}^{-3}\end{array}$ & $\begin{array}{l}\mathrm{EC}_{\mathrm{f}} \\
\%\end{array}$ & $\begin{array}{l}\mathrm{EC}_{\mathrm{bb}} \\
\%\end{array}$ & $\begin{array}{l}\mathrm{OC}_{\mathrm{pri}, \mathrm{f}} \\
\%\end{array}$ & $\begin{array}{l}\mathrm{OC}_{\mathrm{sec}, \mathrm{f}} \\
\%\end{array}$ & $\begin{array}{l}\mathrm{OC}_{\mathrm{bb}} \\
\%\end{array}$ & $\begin{array}{l}\mathrm{OC}_{\mathrm{other}, \mathrm{nf}} \\
\%\end{array}$ \\
\hline XA-MPD & 31.8 & $18(16-19)$ & $5(4-5)$ & $16(12-21)$ & $12(7-16)$ & $25(19-33)$ & $24(15-29)$ \\
XA-HPD & 114.0 & $14(12-15)$ & $4(3-4)$ & $12(10-16)$ & $19(15-22)$ & $16(13-20)$ & $35(30-38)$ \\
BJ-MPD & 22.0 & $13(12-15)$ & $5(4-5)$ & $12(9-16)$ & $32(27-35)$ & $22(17-29)$ & $16(8-20)$ \\
BJ-HPD & 66.9 & $9(8-10)$ & $2(2-3)$ & $8(6-11)$ & $47(44-49)$ & $12(9-17)$ & $21(16-23)$ \\
SH-MPD & 8.1 & $19(17-20)$ & $5(4-5)$ & $17(13-22)$ & $21(15-25)$ & $23(17-31)$ & $16(7-21)$ \\
SH-HPD & 19.8 & $17(15-18)$ & $5(4-5)$ & $15(12-20)$ & $24(19-28)$ & $19(15-24)$ & $21(16-25)$ \\
GZ-MPD & 7.0 & $13(12-15)$ & $10(9-11)$ & $12(9-16)$ & $11(7-14)$ & $45(37-52)$ & $9(0-17)$ \\
GZ-HPD & 29.4 & $17(15-18)$ & $4(4-5)$ & $15(12-20)$ & $18(13-22)$ & $20(16-27)$ & $26(19-30)$ \\
\hline
\end{tabular}

\subsubsection{Sensitivity analysis}

Figure 5 shows the results of the sensitivity test for the average contribution of each source to TC for all sites. Each source is illustrated as a frequency distribution, from which the uncertainties of the source apportionment are deduced as given in Sect. 2.5. We found that $\mathrm{EC}_{\mathrm{bb}}$ was always the smallest contributor $(<10 \%)$ but was still non-negligible for all sites. The distributions of $\mathrm{EC}_{\mathrm{f}}$ and $\mathrm{EC}_{\mathrm{bb}}$ were much narrower than for the different OC sources due to the direct ${ }^{14} \mathrm{C}$ determination of $\mathrm{EC}$ and the indirect calculation of the $\mathrm{OC}$ fractions. $\mathrm{OC}_{\mathrm{bb}}$ and $\mathrm{OC}_{\mathrm{other}} \mathrm{nf}$ were the most uncertain contributors to $\mathrm{TC}$ due to the large variation of the input parameters for LHS calculations, i.e., $(\mathrm{EC} / \mathrm{OC})_{\mathrm{bb}}$ and $(\mathrm{lev} / \mathrm{OC})_{\mathrm{bb}}$. Despite a large spread of $\mathrm{OC}_{\mathrm{sec}, \mathrm{f}}$ and $\mathrm{OC}_{\mathrm{other}} \mathrm{nf}$, the data conclusively show that both contributions were always larger on the heavily than on the moderately polluted days, highlighting the importance of fossil-derived SOC formation and other non-fossil emissions, excluding primary biomass-burning sources. The increased $\mathrm{OC}_{\mathrm{other}} \mathrm{nf}$ is likely due to enhanced SOC formation from biomass-burning and other non-fossil sources (see Sect. 3.3).

\subsection{The relevance of SOC for heavily polluted days}

\subsubsection{Further source apportionment of OC sources}

As explained in Sect. 2.4, $\mathrm{OC}_{\mathrm{f}}$ is apportioned into primary and secondary $\mathrm{OC}$ from fossil sources, whereas $\mathrm{OC}_{\mathrm{nf}}$ is subdivided into primary biomass-burning $\mathrm{OC}\left(\mathrm{OC}_{\mathrm{bb}}\right)$ and the other non-fossil OC $\left(\mathrm{OC}_{\mathrm{other}, \mathrm{nf}}\right)$. As shown in Fig. 6, $\mathrm{OC}_{\mathrm{sec}, \mathrm{f}}$ was generally more abundant than $\mathrm{OC}_{\mathrm{pri}}$, $\mathrm{f}$, suggesting that $\mathrm{SOC}$ is the predominant fraction of $\mathrm{OC}_{\mathrm{f}}$ in Chinese cities during winter. The highest $\mathrm{OC}_{\mathrm{sec}, \mathrm{f}}$-to- $\mathrm{OC}_{\text {pri, } \mathrm{f}}$ ratio (with an average of 4.2) was found in Beijing, indicating the largest SOC formation compared to the other three sites (average $\mathrm{OC}_{\text {sec,f }}$-to-OC $\mathrm{O}_{\text {pri, } \mathrm{f}}$ ratio of 1.3 ), which is in agreement with the higher $\mathrm{OC}_{\mathrm{f}} / \mathrm{EC}_{\mathrm{f}}$ ratios (see Sect. 3.2.2). During heavily polluted days, $\mathrm{OC}_{\text {sec,f-to-OC }}$ pri, f ratios increased, compared to moderately polluted days, on average by $70 \%$ for the four sites. This underlines that the episodes with bad air quality were mainly caused by additional SOC formation and the accumulation of pollutants similar to average winter conditions. The importance of fossil-derived SOC formation was also underlined by ${ }^{14} \mathrm{C}$ measurement in water-soluble $\mathrm{OC}$ during winter 2011 in Beijing and Guangzhou (Zhang et al., $2014 b$ ). Figure 6 shows that $\mathrm{OC}_{\mathrm{bb}}$ was higher than $\mathrm{OC}_{\mathrm{other}} \mathrm{nf}$ on the moderately polluted days for all sites, while it was the opposite on the heavily polluted days. The excess of nonfossil OC concentration for the heavily polluted days was dominated by $\mathrm{OC}_{\text {other, }}$, which was $\sim 2.6$ times as high as $\mathrm{OC}_{\mathrm{bb}}$. The dominating contribution of $\mathrm{OC}_{\mathrm{other}} \mathrm{nf}$ is likely due to the increase of SOC formation from non-fossil sources mainly from biomass-burning emissions, although biogenicderived SOC could not be excluded from SH and GZ where temperatures during the sampling period were above $0^{\circ} \mathrm{C}$. In conclusion, the source apportionment results of the excess carbonaceous aerosols consistently highlight the importance of SOC from both fossil and non-fossil sources. It should be also noted that the condensation of semi-volatile organic aerosols generally may contribute to some extent to the measured secondary organic aerosol (SOA) in winter due to the colder temperature in the northern sites such as Beijing and $\mathrm{Xi}$ 'an, although with current methods and data set this effect is difficult to be quantified. However, the increased SOA between the MPD and HPD measured by the current method should still be dominated by enhanced SOA formation since the temperatures during the moderately and heavily polluted days were not significantly different $(p<0.05)$.

\subsubsection{Relative contribution from $\mathrm{OC}$ and EC source categories to $\mathbf{T C}$}

The contributions of different $\mathrm{OC}$ and $\mathrm{EC}$ source categories to $\mathrm{TC}$ are shown in Table 4 . Fossil sources $\left(\mathrm{EC}_{\mathrm{f}}+\mathrm{OC}_{\mathrm{pri}, \mathrm{f}}+\right.$ $\mathrm{OC}_{\mathrm{sec}, \mathrm{f}}$ ) account for an important contribution at all sites, 

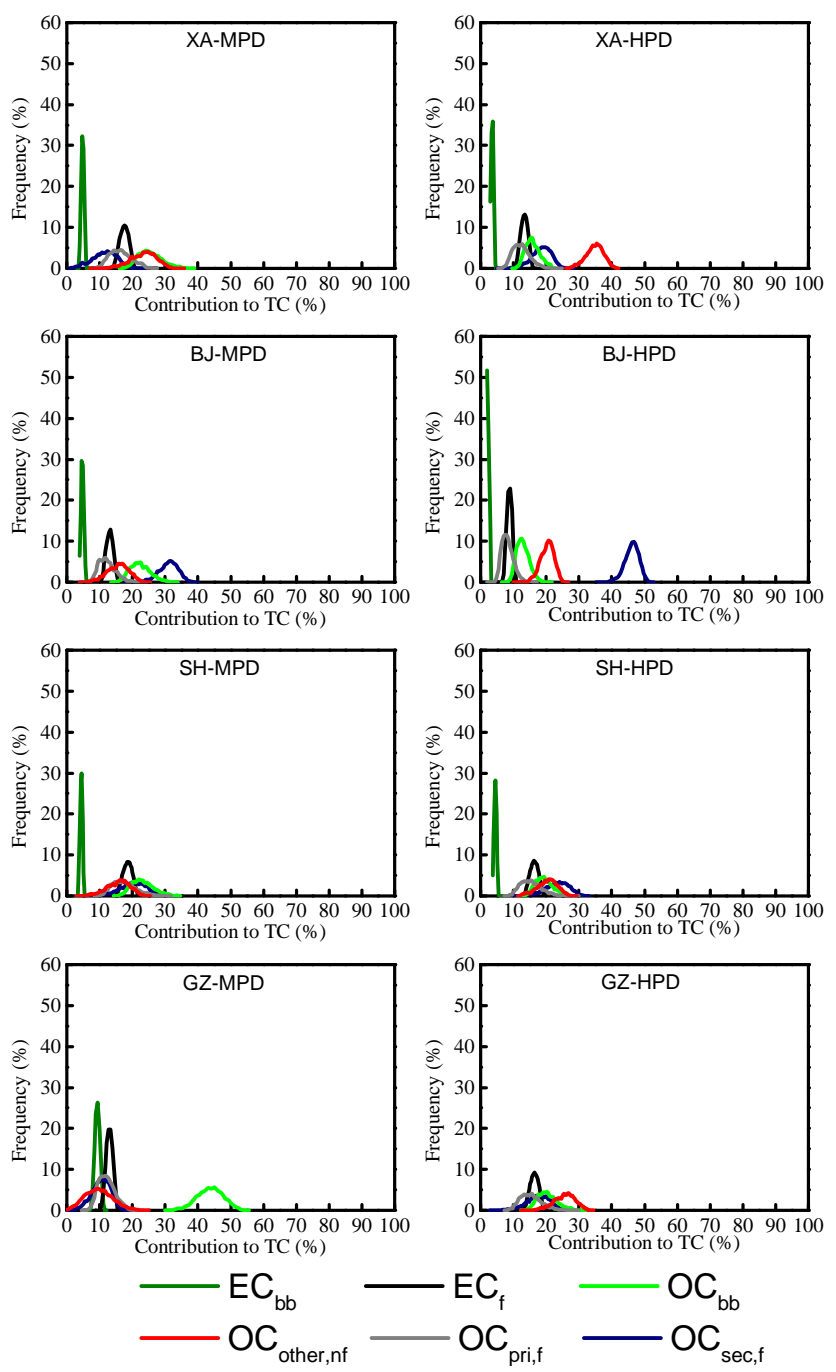

Figure 5. Latin hypercube sampling solutions of frequency distributions of the source contributions to TC from OC and EC source categories (see in Table 4) for samples collected in Xi' an (XA), Beijing (BJ), Shanghai (SH) and Guangzhou (GZ) during the moderately polluted days (MPD) and the heavily polluted days (HPD).

which decreased from Beijing (60\%) to Shanghai (56\%), Xi'an $(45 \%)$ and Guangzhou (43\%). The larger fossil contribution in Beijing can be explained by substantially higher $\mathrm{OC}_{\mathrm{sec}, \mathrm{f}}$ values, which were often $>2$ times as high as the other three sites. However, no remarkable difference was found for the total primary fossil contribution $\left(\mathrm{EC}_{\mathrm{f}}+\mathrm{OC}_{\mathrm{pri}, \mathrm{f}}\right)$ between the heavily and the moderately polluted days. An exception of this tendency was observed in Guangzhou, where the fossil contribution to TC increased by $36 \%$ during the polluted episodes. However, the contribution of $\mathrm{OC}_{\mathrm{sec}, \mathrm{f}}$ to $\mathrm{TC}$ was higher on the heavily polluted days than on the moderately polluted days for all sites, which indicates a significant contribution of fossil SOC to TC during winter haze or smog episodes in China.

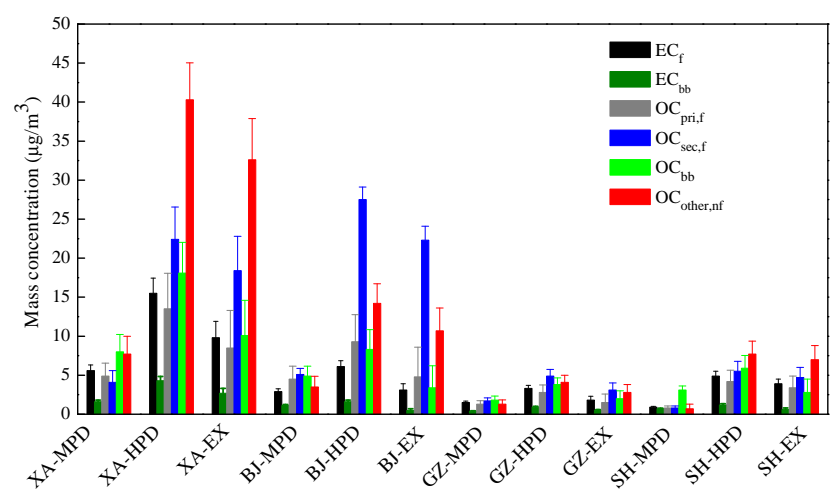

Figure 6. Average mass concentrations of OC and EC from different sources for samples collected in Xi' an (XA), Beijing (BJ), Shanghai (SH) and Guangzhou (GZ) during the moderately polluted days (MPD), heavily polluted days (HPD) and their corresponding excess $(\mathrm{EX}=\mathrm{HPD}-\mathrm{MPD})$. Uncertainty bars represent 10 and 90 percentiles from LHS calculations. See Supplement Fig. S1 for an alternative solution for Beijing assuming a higher contribution of coal combustion as explained in Sect. 3.3.3.

Primary biomass-burning sources $\left(\mathrm{EC}_{\mathrm{bb}}+\mathrm{OC}_{\mathrm{bb}}\right)$ were a large contributor to TC (on average 25, 21, 26 and 39\% in Xi'an, Beijing, Shanghai and Guangzhou, respectively). However, the relative contribution of biomass burning decreased on average from $\sim$ to $\sim 17 \%$ when comparing moderately to heavily polluted days. Therefore, primary biomassburning emissions were not a major additional source during heavily polluted days.

A considerable fraction of $\mathrm{TC}$ originated from $\mathrm{OC}_{\mathrm{other}} \mathrm{nf}$ with a mean contribution of $21 \%$ for all sites. The presence of $\mathrm{OC}_{\mathrm{other}} \mathrm{nf}$ is unlikely attributed to primary or secondary biogenic particles as biogenic emissions are very low during winter, at least in northern China, although these can be enriched due to favoring condensation of semi-volatile organic compounds into the particle phase at colder temperatures. In combination with the observation of enhanced fossil SOC formation, we assume that this excess is mainly attributed to SOC formation from non-fossil, non-biogenic precursors (i.e., mainly from biomass-burning emissions). Furthermore, SOC formation from these non-fossil volatile organic compounds may be enhanced when they are mixed with anthropogenic pollutants such as volatile organic compounds (VOCs) and $\mathrm{NO}_{\mathrm{x}}$ (Weber et al., 2007; Hoyle et al., 2011).

As the $\mathrm{OC}_{\text {sec,f } \mathrm{f}}$ and $\mathrm{OC}_{\mathrm{other}}$, nf contributions were always considerably higher on the most polluted days compared to the moderately polluted days and the increase of primary sources (such as $\mathrm{EC}_{\mathrm{bb}}, \mathrm{OC}_{\mathrm{bb}}$ and $\mathrm{OC}_{\mathrm{pri}, \mathrm{f}}$ ) was less prominent (see Fig. 6), we conclude that the increment of TC on the heavily polluted days was mainly driven by the increase of SOC from both fossil-fuel and non-fossil emissions. This is also underlined in Fig. 6 by the composition of the excess for the heavily polluted days. 


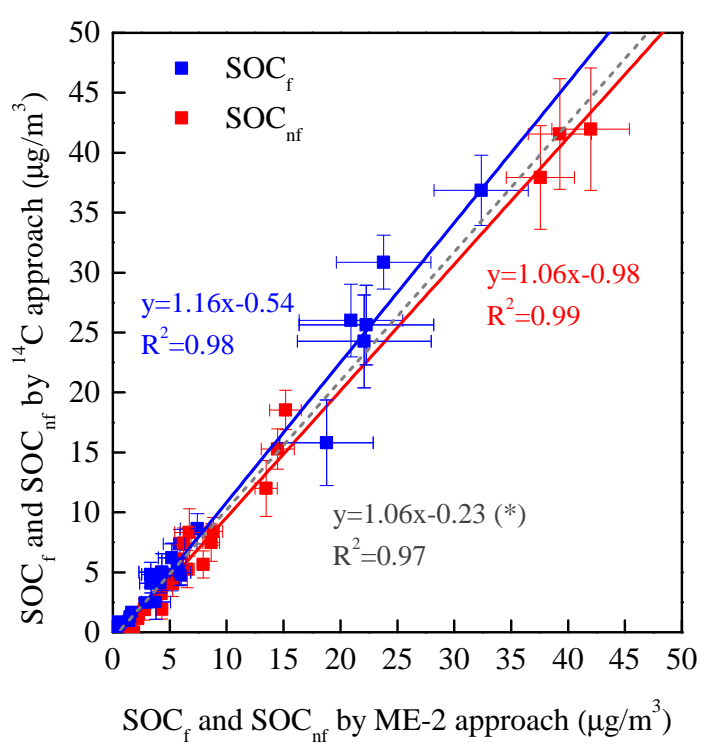

Figure 7. Comparison of secondary OC from fossil and non-fossil sources (i.e., $\mathrm{SOC}_{\mathrm{f}}$ and $\mathrm{SOC}_{\mathrm{nf}}$, respectively) resolved by the ${ }^{14} \mathrm{C}$ and ME-2 approaches. The dashed line denotes a linear regression fit of $\mathrm{SOC}_{\mathrm{f}}$ when excluding data from Beijing, yielding an alternative regression slope marked with an asterisk $(*)$. Note that the intercepts are insignificant for all three cases.

\subsubsection{Comparison with multi-linear engine source apportionment}

In a parallel study from the same sites and episodes (Huang et al., 2014), the multi-linear engine receptor model (Canonaco et al., 2013) was used to estimate the OC contribution from different factors including coal, traffic, dust-related, cooking and secondary sources. This model includes EC/OC, ions and organic marker compounds (polycyclic aromatic hydrocarbons (PAHs), oxygenated PAHs (o-PAHs), resin acids, anhydrous sugars, lignin pyrolysis products and hopanes) in addition to high-resolution Aerodyne aerosol mass spectra from offline analyses of nebulized water extracts from filter samples by a high-resolution time-of-flight aerosol mass spectrometer (HR-ToF-AMS; Daellenbach et al., 2015). For comparison to the results from this work, sources resolved by the ME-2 approach are further classified into the following basic classes: fossil primary $\mathrm{OC}\left(\mathrm{POC}_{\mathrm{f}}\right)$, non-fossil primary $\mathrm{OC}\left(\mathrm{POC}_{\mathrm{nf}}\right)$, fossil secondary $\mathrm{OC}\left(\mathrm{SOC}_{\mathrm{f}}\right)$ and non-fossil secondary $\mathrm{OC}\left(\mathrm{SOC}_{\mathrm{nf}}\right)$. Figure 7 shows a significant linear correlation between the two approaches $(p<0.01, n=24$, all samples are included), underscoring the proper choices of the selected source profiles in this study (i.e., inputs for LHS). A very good agreement between the two methods is found for $\mathrm{SOC}_{\mathrm{nf}}$, whereas a deviation of $\sim 13 \%$ occurs for $\mathrm{SOC}_{\mathrm{f}}$, possibly due to uncertainties in both models. It is important to note that such a difference is not observed $(p<0.01)$ if we exclude the data from Beijing. $\mathrm{SOC}_{\mathrm{f}}$ may be overestimated if we have underestimated the contribution of coal combus- tion to fossil-fuel derived EC ( $p$ in Eq. 8) in Beijing. The findings of Huang et al. (2014) suggest that coal combustion is substantially higher in this city compared to the other sites. Increasing the value of $p$ by a factor of 2 (i.e., from 0.35 to 0.70) for Beijing decreases the contribution of $\mathrm{SOC}_{\mathrm{f}}$ to the benefit of $\mathrm{POC}_{\mathrm{f}}$, whereas the other components $\left(\mathrm{EC}_{\mathrm{f}}, \mathrm{EC}_{\mathrm{bb}}\right.$, $\left.\mathrm{OC}_{\mathrm{bb}}, \mathrm{OC}_{\mathrm{other}, \mathrm{nf}}\right)$ are independent of the choice of the $p$ value (see Table S2 and Fig. S1). This modification improves the agreement of $\mathrm{SOC}_{\mathrm{f}}$ between both approaches as shown in Fig. 7. Furthermore, it decreases the $\mathrm{OC}_{\text {sec, }}$-to- $-\mathrm{OC}_{\text {pri, }}$ ratio of Beijing from 2.7 and 5.9 to 1.2 and 2.9 for the moderately and heavily polluted days, respectively. As a consequence, these values become better comparable with those of the other cities but still underline the importance of secondary aerosol formation during the heavily polluted days.

\section{Conclusions}

Source apportionment of the carbonaceous aerosol in $\mathrm{PM}_{2.5}$ during a severe winter pollution episode in 2013 in China was conducted at four major cities: Xi'an, Beijing, Shanghai and Guangzhou. Statistical analysis of concentrations of OC and EC, anhydrosugars and ${ }^{14} \mathrm{C}$ contents of $\mathrm{OC}$ and EC using Latin hypercube sampling allowed a quantitative estimation of six different sources. These sources included $\mathrm{EC}$ from the combustion of biomass $\left(\mathrm{EC}_{\mathrm{bb}}\right)$ and fossil fuels $\left(\mathrm{EC}_{\mathrm{f}}\right), \mathrm{OC}$ from fossil emissions including primary and secondary sources $\left(\mathrm{OC}_{\mathrm{pri}, \mathrm{f}}\right.$ and $\mathrm{OC}_{\mathrm{sec}, \mathrm{f}}$, respectively), and $\mathrm{OC}$ from non-fossil sources including primary biomass burning and all the other non-fossil $\mathrm{OC}\left(\mathrm{OC}_{\mathrm{bb}}\right.$ and $\mathrm{OC}_{\mathrm{other}} \mathrm{nf}$, respectively). A sensitivity analysis of the LHS simulation showed the robustness of our results: the uncertainty of the different emission sources was usually below $20 \%$ of TC, which was mainly achieved by the combination of different isotopic and molecular markers.

Fossil emissions predominated EC with a mean contribution of $75 \pm 8 \%$ at all sites. The remaining $25 \pm 8 \%$ was attributed to biomass-burning sources, and the presence of the latter was also confirmed by other biomass-burning markers such as levoglucosan and water-soluble potassium. The fossil contribution to $\mathrm{OC}$ was lower than for $\mathrm{EC}$ and was highest in Beijing $(58 \pm 5 \%)$ and decreased in the following order: Shanghai $(49 \pm 2 \%)>$ Xi' an $(38 \pm 3 \%)>$ Guangzhou $(35 \pm 7 \%)$.

Conversely, non-fossil sources accounted on the average for $55 \pm 10 \%$ and $48 \pm 9 \%$ of OC and TC, respectively. Air pollution from the neighboring rural regions may have contributed substantially to non-fossil carbon of urban aerosols because biofuel usage is more common for heating and cooking in such regions during wintertime in China. The average contribution of non-fossil $\mathrm{OC}$ from $\mathrm{OC}_{\mathrm{bb}}$ was found to be $40 \pm 8 \%, 48 \pm 18 \%, 53 \pm 4 \%$ and $65 \pm 26 \%$ for Xi' an, Beijing, Shanghai and Guangzhou, respectively. 
A considerable fraction of OC was identified as SOC. We found that $\mathrm{OC}_{\mathrm{sec}, \mathrm{f}}$ dominated over $\mathrm{OC}_{\mathrm{pri}, \mathrm{f}}$ for all samples (i.e., portions of TC of $23 \pm 11 \%$ compared to $13 \pm 3 \%$, respectively), strongly implying an importance of fossilderived SOC to urban (often polluted) aerosols in China. Furthermore, we divided the samples into two episodes heavily polluted and moderately polluted days - depending on PM mass. We found that the relative $\mathrm{OC}_{\mathrm{other}} \mathrm{nf}$ contributions tended to be higher on the heavily polluted days at all sites, which was mainly attributed to enhanced SOC formation from non-fossil precursors such as biomass-burning emissions. Even though a significant increase of absolute mass concentrations of primary emissions (both fossil and non-fossil sources) was found on the heavily compared to moderately polluted days, their relative contribution to TC was even decreased, while SOC contributions from both fossil and non-fossil sources were substantially increased. This finding was consistently observed for all sites, showing the importance of SOC during severe haze events in China.

\section{The Supplement related to this article is available online at doi:10.5194/acp-15-1299-2015-supplement.}

Acknowledgements. Yanlin Zhang acknowledges partial support from the Swiss National Science Foundation Fellowship.

Edited by: T. Röckmann

\section{References}

Bernardoni, V., Calzolai, G., Chiari, M., Fedi, M., Lucarelli, F., Nava, S., Piazzalunga, A., Riccobono, F., Taccetti, F., Valli, G., and Vecchi, R.: Radiocarbon analysis on organic and elemental carbon in aerosol samples and source apportionment at an urban site in Northern Italy, J. Aerosol Sci., 56, 88-99, 2013.

Canonaco, F., Crippa, M., Slowik, J. G., Baltensperger, U., and Prévôt, A. S. H.: SoFi, an IGOR-based interface for the efficient use of the generalized multilinear engine (ME-2) for the source apportionment: ME-2 application to aerosol mass spectrometer data, Atmos. Meas. Tech., 6, 3649-3661, 2013,

http://www.atmos-meas-tech.net/6/3649/2013/.

Cao, F., Zhang, Y.-L., Szidat, S., Zapf, A., Wacker, L., and Schwikowski, M.: Microgram level radiocarbon determination of carbonaceous particles in firn samples: pre-treatment and OC/EC separation, Radiocarbon, 55, 383-390 2013.

Cao, G. L., Zhang, X. Y., Gong, S. L., An, X. Q., and Wang, Y. Q.: Emission inventories of primary particles and pollutant gases for China, Chin. Sci. Bull., 56, 781-788, 2011a.

Cao, J. J., Chow, J. C., Tao, J., Lee, S. C., Watson, J. G., Ho, K. F., Wang, G. H., Zhu, C. S., and Han, Y. M.: Stable carbon isotopes in aerosols from Chinese cities: Influence of fossil fuels, Atmos. Environ., 45, 1359-1363, 2011b.
Cao, J. J., Lee, S. C., Chow, J. C., Watson, J. G., Ho, K. F., Zhang, R. J., Jin, Z. D., Shen, Z. X., Chen, G. C., Kang, Y. M., Zou, S. C., Zhang, L. Z., Qi, S. H., Dai, M. H., Cheng, Y., and $\mathrm{Hu}, \mathrm{K}$. : Spatial and seasonal distributions of carbonaceous aerosols over China, J. Geophys. Res., 112, D22S11, doi:10.1029/2006JD008205, 2007.

Cao, J. J., Shen, Z. X., Chow, J. C., Watson, J. G., Lee, S. C., Tie, X. X., Ho, K. F., Wang, G. H., and Han, Y. M.: Winter and summer $\mathrm{PM}_{2.5}$ chemical compositions in fourteen chinese cities, J. Air Waste Manage. Assoc., 62, 1214-1226, 2012.

Carlton, A. G., Wiedinmyer, C., and Kroll, J. H.: A review of Secondary Organic Aerosol (SOA) formation from isoprene, Atmos. Chem. Phys., 9, 4987-5005, 2009,

http://www.atmos-chem-phys.net/9/4987/2009/.

Cavalli, F., Viana, M., Yttri, K. E., Genberg, J., and Putaud, J. P. Toward a standardised thermal-optical protocol for measuring atmospheric organic and elemental carbon: the EUSAAR protocol, Atmos. Meas. Tech., 3, 79-89, 2010, http://www.atmos-meas-tech.net/3/79/2010/.

Chan, C. K., and Yao, X.: Air pollution in mega cities in China, Atmos. Environ., 42, 1-42, 2008.

Chen, B., Andersson, A., Lee, M., Kirillova, E. N., Xiao, Q., Krusa, M., Shi, M., Hu, K., Lu, Z., Streets, D. G., Du, K., and Gustafsson, O.: Source forensics of black carbon aerosols from china, Environ. Sci. Technol., 47, 9102-9108, 2013.

Cheng, Y., Engling, G., He, K. B., Duan, F. K., Ma, Y. L., Du, Z. Y., Liu, J. M., Zheng, M., and Weber, R. J.: Biomass burning contribution to Beijing aerosol, Atmos. Chem. Phys., 13, 77657781, 2013,

http://www.atmos-chem-phys.net/13/7765/2013/.

Donkelaar, A. V., Martin, R. V., Brauer, M., Kahn, R., Levy, R., Verduzco, C., and Villeneuve, P. J.: Global estimates of ambient fine particulate matter concentrations from satellite-based aerosol optical depth: development and application, Environ. Health Persp., 118, 847-855, 2010.

Fine, P. M., Cass, G. R., and Simoneit, B. R. T.: Chemical characterization of fine particle emissions from the wood stove combustion of prevalent United States tree species, Environ. Eng. Sci., 21, 705-721, 2004.

Gelencsér, A., May, B., Simpson, D., Sánchez-Ochoa, A., KasperGiebl, A., Puxbaum, H., Caseiro, A., Pio, C., and Legrand, M.: Source apportionment of $\mathrm{PM}_{2.5}$ organic aerosol over Europe: primary/secondary, natural/anthropogenic, and fossil/biogenic origin, J. Geophys. Res., 112, D23S04, doi:10.1029/2006jd008094, 2007.

Genberg, J., Hyder, M., Stenström, K., Bergström, R., Simpson, D., Fors, E. O., Jönsson, J. A., and Swietlicki, E.: Source apportionment of carbonaceous aerosol in southern Sweden, Atmos. Chem. Phys., 11, 11387-11400, doi:10.5194/acp-1111387-2011, 2011.

Gilardoni, S., Vignati, E., Cavalli, F., Putaud, J. P., Larsen, B. R., Karl, M., Stenström, K., Genberg, J., Henne, S., and Dentener, F.: Better constraints on sources of carbonaceous aerosols using a combined ${ }^{14} \mathrm{C}$ - macro tracer analysis in a European rural background site, Atmos. Chem. Phys., 11, 5685-5700, doi:10.5194/acp-11-5685-2011, 2011.

Gustafsson, O., Krusa, M., Zencak, Z., Sheesley, R. J., Granat, L., Engstrom, E., Praveen, P. S., Rao, P. S., Leck, C., and Rodhe, H.: 
Brown clouds over South Asia: biomass or fossil fuel combustion?, Science, 323, 495-498, 2009.

He, L. Y., Hu, M., Zhang, Y. H., Huang, X. F., and Yao, T. T.: Fine particle emissions from on-road vehicles in the Zhujiang Tunnel, China, Environ. Sci. Technol., 42, 4461-4466, 2008.

Heal, M.: The application of carbon-14 analyses to the source apportionment of atmospheric carbonaceous particulate matter: a review, Anal. Bioanal. Chem., 406, 81-98, 2014.

Hoyle, C. R., Boy, M., Donahue, N. M., Fry, J. L., Glasius, M., Guenther, A., Hallar, A. G., Huff Hartz, K., Petters, M. D., Petäjä, T., Rosenoern, T., and Sullivan, A. P.: A review of the anthropogenic influence on biogenic secondary organic aerosol, Atmos. Chem. Phys., 11, 321-343, doi:10.5194/acp-11-321-2011, 2011.

Huang, K., Zhuang, G., Lin, Y., Wang, Q., Fu, J. S., Fu, Q., Liu, T., and Deng, C.: How to improve the air quality over megacities in China: pollution characterization and source analysis in Shanghai before, during, and after the 2010 World Expo, Atmos. Chem. Phys., 13, 5927-5942, doi:10.5194/acp-13-5927-2013, 2013.

Huang, R.-J., Zhang, Y., Bozzetti, C., Ho, K.-F., Cao, J., Han, Y., Dällenbach, K. R., Slowik, J. G., Platt, S. M., Canonaco, F., Zotter, P., Wolf, R., Pieber, S. M., Bruns, E. A., Crippa, M., Ciarelli, G., Piazzalunga, A., Schwikowski, M., Abbaszade, G., Schnelle-Kreis, J., Zimmermann, R., An, Z., Szidat, S., Baltensperger, U., Haddad, I. E., and Prévôt, A. S. H.: High secondary aerosol contribution to particulate pollution during haze events in China, Nature, 514, 218-222, 2014.

Huang, X. F., Yu, J. Z., He, L. Y., and Hu, M.: Size distribution characteristics of elemental carbon emitted from Chinese vehicles: Results of a tunnel study and atmospheric implications, Environ. Sci. Technol., 40, 5355-5360, 2006.

IPCC: Climate change 2013: The physical science basis. contribution of working group I to the fifth assessment report of the intergovernmental panel on climate change, Cambridge University Press, Cambridge, United Kingdom and New York, NY, USA, 1533 pp., 2013.

Lai, S. C., Zou, S. C., Cao, J. J., Lee, S. C., and Ho, K. F.: Characterizing ionic species in $\mathrm{PM}_{2.5}$ and $\mathrm{PM}_{10}$ in four Pearl River Delta cities, South China, J. Environ. Sci., 19, 939-947, 2007.

Levin, I., Naegler, T., Kromer, B., Diehl, M., Francey, R. J., GomezPelaez, A. J., Steele, L. P., Wagenbach, D., Weller, R., and Worthy, D. E.: Observations and modelling of the global distribution and long-term trend of atmospheric ${ }^{14} \mathrm{CO}_{2}$, Tellus B, 62, 26-46, 2010.

Liu, D., Li, J., Zhang, Y., Xu, Y., Liu, X., Ding, P., Shen, C., Chen, Y., Tian, C., and Zhang, G.: The use of levoglucosan and radiocarbon for source apportionment of $\mathrm{PM}_{2.5}$ carbonaceous aerosols at a background site in East China, Environ. Sci. Technol., 47, 10454-10461, 2013.

Minguillón, M. C., Perron, N., Querol, X., Szidat, S., Fahrni, S. M., Alastuey, A., Jimenez, J. L., Mohr, C., Ortega, A. M., Day, D. A., Lanz, V. A., Wacker, L., Reche, C., Cusack, M., Amato, F., Kiss, G., Hoffer, A., Decesari, S., Moretti, F., Hillamo, R., Teinilä, K., Seco, R., Peñuelas, J., Metzger, A., Schallhart, S., Müller, M., Hansel, A., Burkhart, J. F., Baltensperger, U., and Prévôt, A. S. H.: Fossil versus contemporary sources of fine elemental and organic carbonaceous particulate matter during the DAURE campaign in Northeast Spain, Atmos. Chem. Phys., 11, 12067-12084, doi:10.5194/acp-11-12067-2011, 2011.
Mohn, J., Szidat, S., Fellner, J., Rechberger, H., Quartier, R., Buchmann, B., and Emmenegger, L.: Determination of biogenic and fossil $\mathrm{CO}_{2}$ emitted by waste incineration based on ${ }^{14} \mathrm{CO}_{2}$ and mass balances, Bioresour. Technol., 99, 6471-6479, 2008.

Nordin, E. Z., Eriksson, A. C., Roldin, P., Nilsson, P. T., Carlsson, J. E., Kajos, M. K., Hellén, H., Wittbom, C., Rissler, J., Löndahl, J., Swietlicki, E., Svenningsson, B., Bohgard, M., Kulmala, M., Hallquist, M., and Pagels, J. H.: Secondary organic aerosol formation from idling gasoline passenger vehicle emissions investigated in a smog chamber, Atmos. Chem. Phys., 13, 6101-6116, doi:10.5194/acp-13-6101-2013, 2013.

Orasche, J., Schnelle-Kreis, J., Abbaszade, G., and Zimmermann, R.: Technical Note: In-situ derivatization thermal desorption GC-TOFMS for direct analysis of particle-bound non-polar and polar organic species, Atmos. Chem. Phys., 11, 8977-8993, doi:10.5194/acp-11-8977-2011, 2011.

Paatero, P. and Tapper, U.: Positive matrix factorization - A nonnegative factor model with optimal utilization of error-estimates of data values, Environmetricsz, 5, 111-126, 1994.

Paatero, P. and Hopke, P. K.: Rotational tools for factor analytic models, J. Chemom., 23, 91-100, 2009.

Pöschl, U.: Atmospheric aerosols: composition, transformation, climate and health effects, Angew. Chem. Int. Edit., 44, 7520-7540, 2005.

Puxbaum, H., Caseiro, A., Sánchez-Ochoa, A., Kasper-Giebl, A., Claeys, M., Gelencsér, A., Legrand, M., Preunkert, S., and Pio, C.: Levoglucosan levels at background sites in Europe for assessing the impact of biomass combustion on the European aerosol background, J. Geophys. Res., 112, D23S05, doi:10.1029/2006jd008114, 2007.

Sang, X. F., Chan, C. Y., Engling, G., Chan, L. Y., Wang, X. M., Zhang, Y. N., Shi, S., Zhang, Z. S., Zhang, T., and Hu, M.: Levoglucosan enhancement in ambient aerosol during springtime transport events of biomass burning smoke to Southeast China, Tellus B, 63, 129-139, 2011.

Sang, X. F., Zhang, Z. S., Chan, C. Y., and Engling, G.: Source categories and contribution of biomass smoke to organic aerosol over the southeastern Tibetan Plateau, Atmos. Environ., 78, 113 123, 2013.

Schmidl, C., Marr, I. L., Caseiro, A., Kotianová, P., Berner, A., Bauer, H., Kasper-Giebl, A., and Puxbaum, H.: Chemical characterisation of fine particle emissions from wood stove combustion of common woods growing in mid-European Alpine regions, Atmos. Environ., 42, 126-141, 2008.

Schnelle-Kreis, J., Sklorz, M., Peters, A., Cyrys, J., and Zimmermann, R.: Analysis of particle-associated semi-volatile aromatic and aliphatic hydrocarbons in urban particulate matter on a daily basis, Atmos. Environ., 39, 7702-7714, 2005.

Simoneit, B. R. T., Schauer, J. J., Nolte, C. G., Oros, D. R., Elias, V. O., Fraser, M. P., Rogge, W. F., and Cass, G. R.: Levoglucosan, a tracer for cellulose in biomass burning and atmospheric particles, Atmos. Environ., 33, 173-182, 1999.

Stuiver, M. and Polach, H. A.: Discussion: Reporting of 14C data, Radiocarbon, 19, 355-363, 1977.

Szidat, S., Jenk, T. M., Synal, H.-A., Kalberer, M., Wacker, L., Hajdas, I., Kasper-Giebl, A., and Baltensperger, U.: Contributions of fossil fuel, biomass-burning, and biogenic emissions to carbonaceous aerosols in Zurich as traced by ${ }^{14} \mathrm{C}$, J. Geophys. Res., 111, D07206, doi:10.1029/2005jd006590, 2006. 
Szidat, S., Prévôt, A. S. H., Sandradewi, J., Alfarra, M. R., Synal, H. A., Wacker, L., and Baltensperger, U.: Dominant impact of residential wood burning on particulate matter in Alpine valleys during winter, Geophys. Res. Lett., 34, L05820, doi:10.1029/2006g1028325, 2007.

Szidat, S.: Sources of Asian haze, Science, 323, 470-471, 2009.

Szidat, S., Ruff, M., Perron, N., Wacker, L., Synal, H.-A., Hallquist, M., Shannigrahi, A. S., Yttri, K. E., Dye, C., and Simpson, D.: Fossil and non-fossil sources of organic carbon (OC) and elemental carbon (EC) in Goeteborg, Sweden, Atmos. Chem. Phys., 9, 1521-1535, 2009,

http://www.atmos-chem-phys.net/9/1521/2009/.

Szidat, S., Salazar, G. A., Vogel, E., Battaglia, M., Wacker, L., Synal, H.-A., and Türler, A.: ${ }^{14} \mathrm{C}$ Analysis and Sample Preparation at the New Bern Laboratory for the Analysis of Radiocarbon with AMS (LARA), Radiocarbon, 56, 561-566, 2014.

Viana, M., Reche, C., Amato, F., Alastuey, A., Querol, X., Moreno, T., Lucarelli, F., Nava, S., Cazolai, G., Chiari, M., and Rico, M.: Evidence of biomass burning aerosols in the Barcelona urban environment during winter time, Atmos. Environ., 72, 81-88, 2013.

Wacker, L., Fahrni, S. M., Hajdas, I., Molnar, M., Synal, H. A., Szidat, S., and Zhang, Y. L.: A versatile gas interface for routine radiocarbon analysis with a gas ion source, Nucl. Instrum. Meth. B, 294, 315-319, 2013.

Weber, R. J., Sullivan, A. P., Peltier, R. E., Russell, A., Yan, B., Zheng, M., de Gouw, J., Warneke, C., Brock, C., Holloway, J. S., Atlas, E. L., and Edgerton, E.: A study of secondary organic aerosol formation in the anthropogenicinfluenced southeastern United States, J. Geophys. Res., 112, D13302, doi:10.1029/2007jd008408, 2007.

Weilenmann, M., Favez, J.-Y., and Alvarez, R.: Cold-start emissions of modern passenger cars at different low ambient temperatures and their evolution over vehicle legislation categories, Atmos. Environ., 43, 2419-2429, 2009.

WHO: Air Quality Guidelines: Global Update 2005: Particulate Matter, Ozone, Nitrogen Dioxide and Sulfur Dioxide, World Health Organization, 2006.

Yang, F., Tan, J., Zhao, Q., Du, Z., He, K., Ma, Y., Duan, F., Chen, G., and Zhao, Q.: Characteristics of $\mathrm{PM}_{2.5}$ speciation in representative megacities and across China, Atmos. Chem. Phys., 11, 5207-5219, doi:10.5194/acp-11-5207-2011, 2011.

Yttri, K. E., Simpson, D., Stenström, K., Puxbaum, H., and Svendby, T.: Source apportionment of the carbonaceous aerosol in Norway - quantitative estimates based on ${ }^{14} \mathrm{C}$, thermal-optical and organic tracer analysis, Atmos. Chem. Phys., 11, 9375-9394, doi:10.5194/acp-11-9375-2011, 2011.
Zhang, Q., Streets, D. G., He, K., and Klimont, Z.: Major components of China's anthropogenic primary particulate emissions, Environ. Res. Lett., 2, 045027, doi:10.1088/17489326/2/4/045027, 2007.

Zhang, T., Claeys, M., Cachier, H., Dong, S. P., Wang, W., Maenhaut, W., and Liu, X. D.: Identification and estimation of the biomass burning contribution to Beijing aerosol using levoglucosan as a molecular marker, Atmos. Environ., 42, 7013-7021, 2008.

Zhang, Y. L., Perron, N., Ciobanu, V. G., Zotter, P., Minguillón, M. C., Wacker, L., Prévôt, A. S. H., Baltensperger, U., and Szidat, S.: On the isolation of OC and EC and the optimal strategy of radiocarbon-based source apportionment of carbonaceous aerosols, Atmos. Chem. Phys., 12, 10841-10856, doi:10.5194/acp-12-10841-2012, 2012.

Zhang, Y. L., Zotter, P., Perron, N., Prévôt, A. S. H., Wacker, L., and Szidat, S.: Fossil and non-fossil sources of different carbonaceous fractions in fine and coarse particles by radiocarbon measurement, Radiocarbon, 55, 1510-1520, 2013.

Zhang, Y.-L., Li, J., Zhang, G., Zotter, P., Huang, R.-J., Tang, J.H., Wacker, L., Prévôt, A. S. H., and Szidat, S.: Radiocarbonbased source apportionment of carbonaceous aerosols at a regional background site on hainan Island, South China, Environ. Sci. Technol., 48, 2651-2659, 2014a.

Zhang, Y.-L., Liu, J.-W., Salazar, G. A., Li, J., Zotter, P., Zhang, G., Shen, R.-R., Schäfer, K., Schnelle-Kreis, J., Prévôt, A. S. H., and Szidat, S.: Micro-scale $(\mu \mathrm{g})$ radiocarbon analysis of watersoluble organic carbon in aerosol samples, Atmos. Environ., 97, 1-5, 2014b.

Zhao, P. S., Dong, F., He, D., Zhao, X. J., Zhang, X. L., Zhang, W. Z., Yao, Q., and Liu, H. Y.: Characteristics of concentrations and chemical compositions for $\mathrm{PM}_{2.5}$ in the region of Beijing, Tianjin, and Hebei, China, Atmos. Chem. Phys., 13, 4631-4644, doi:10.5194/acp-13-4631-2013, 2013.

Zhi, G., Chen, Y., Feng, Y., Xiong, S., Li, J., Zhang, G., Sheng, G., and $\mathrm{Fu}, \mathrm{J} .:$ Emission Characteristics of Carbonaceous Particles from Various Residential Coal-Stoves in China, Environ. Sci. Technol., 42, 3310-3315, 2008.

Zotter, P., El-Haddad, I., Zhang, Y., Hayes, P. L., Zhang, X., Lin, Y.H., Wacker, L., Schnelle-Kreis, J., Abbaszade, G., Zimmermann, R., Surratt, J. D., Weber, R., Jimenez, J. L., Szidat, S., Baltensperger, U., and Prévôt, A. S. H.: Diurnal cycle of fossil and non-fossil carbon using radiocarbon analyses during CalNex, J. Geophys. Res., 119, 6818-6835, 2014. 